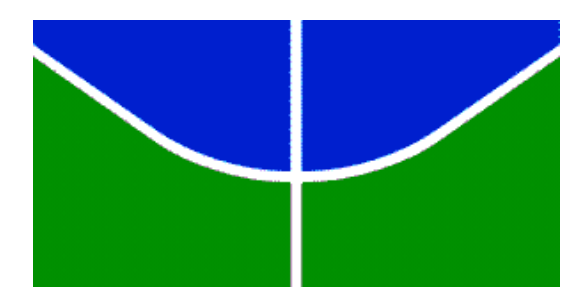

UNIVERSIDADE DE BRASÍLIA

CARACTERIZAÇÃO MOLECULAR DE CEPAS DE LISTERIA MONOCYTOGENES ORIUNDAS DE CORTE BOVINO E ABATEDOUROS FRIGORÍFICOS DE BOVINOS LOCALIZADO NO DISTRITO FEDERAL

JOANA MARCHESINI PALMA

DISSERTAÇÃO DE MESTRADO

EM SAÚDE ANIMAL

BRASÍLIA / DF / 2016 


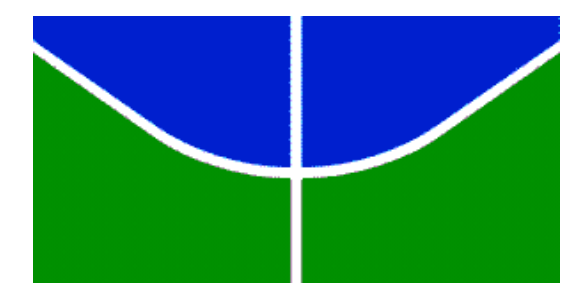

UNIVERSIDADE DE BRASÍLIA

CARACTERIZAÇÃO MOLECULAR DE CEPAS DE LISTERIA MONOCYTOGENES ORIUNDAS DE CORTE BOVINO E ABATEDOUROS FRIGORÍFICOS DE BOVINOS LOCALIZADO NO DISTRITO FEDERAL

JOANA MARCHESINI PALMA

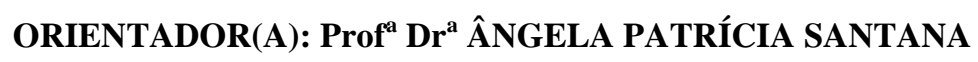

DISSERTAÇÃO DE MESTRADO

EM SAÚDE ANIMAL

PUBLICAÇÃO:

BRASÍLIA/

DF/ 2016 


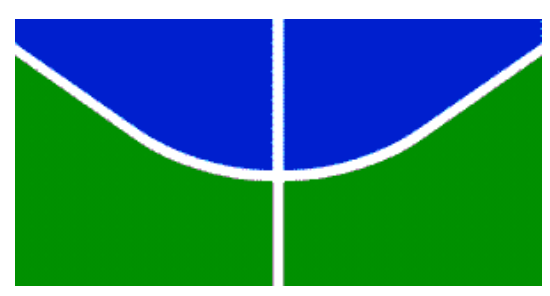

UNIVERSIDADE DE BRASÍLIA

\title{
CARACTERIZAÇÃO MOLECULAR DE CEPAS DE LISTERIA MONOCYTOGENES ORIUNDAS DE CORTE BOVINO E ABATEDOUROS FRIGORÍFICOS DE BOVINOS LOCALIZADO NO DISTRITO FEDERAL
}

\author{
JOANA MARCHESINI PALMA
}

DISSERTAÇ̃̃o DE MESTRADO SUBMETIDA AO PROGRAMA DE Pós-gRAduAÇ̃̃o EM SAÚdE ANIMAL, COMO PARTE DOS REQUISITOS NECESSÁRIOS À OBTENCÃO DO TÍtulo DE MESTRE EM SAÚdE ANIMAL.

APROVADO POR:

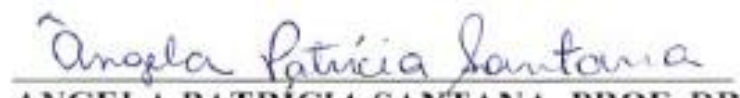

ANGELA PATRICIA SANTANA, PROF. DR. UNIVERSIDADE DE BRASILIA (ORIENTADOR)

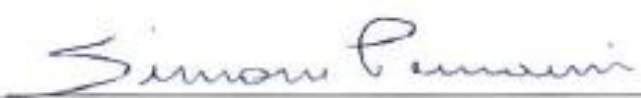

SIMONE PERECMANIS, PROF. DR. UNIVERSIDADE DE BRASILIA (EXAMINADQR INTERNO)

JANICE LISBOA DE MARCO, PROF. DR. UNIVERSIDADE DE BRASILIA (EXAMINADOR EXTERNO)

BRASÍLIA/DF, 27 de janeiro de 2016 


\title{
REFERÊNCIA BIBLIOGRÁFICA E CATALOGAÇÃO
}

MARCHESINI, J. M. Caracterização molecular de cepas de Listeria monocytogenes oriundas de corte bovino e abatedouros frigoríficos de bovinos localizado no distrito federal. Brasília: Faculdade de Agronomia e Medicina Veterinária, Universidade de Brasília, 2016, 58p. Dissertação de Mestrado.

\begin{abstract}
Documento formal, autorizando reprodução desta dissertação de mestrado para empréstimo ou comercialização, exclusivamente para fins acadêmicos, foi passado pelo autor à Universidade de Brasília e acha-se arquivado na Secretaria do Programa. $O$ autor reserva para si os outros direitos autorais, de publicação. Nenhuma parte desta dissertação de mestrado pode ser reproduzida sem a autorização por escrito do autor. Citações são estimuladas, desde que citada a fonte.
\end{abstract}

\section{FICHA CATALOGRÁFICA}

\section{Palma, Joana Marchesini}

Caracterização molecular de cepas de Listeria monocytogenes oriundas de corte bovino e abatedouros frigoríficos de bovinos localizado no distrito federal / Joana Marchesini Palma; orientação de Ângela Patrícia Santana, 2016. 58p.: il.

Dissertação de Mestrado (M) - Universidade de Brasília/Faculdade de

Agronomia e Medicina Veterinária, 2016.

1. PFGE. 2. Listeria monocytogenes. 3. Carne bovina. Santana, A.P. II Caracterização molecular de Listeria monocytogenes oriundas de cortes cárneos bovinos e de abatedouros frigoríficos de bovinos localizados no Distrito Federal.

CDD ou CDU

Agris / FAO 


\section{AGRADECIMENTOS}

Agradeço primeiramente aos meus pais, Ernani e Paola, pela força, pelos conselhos e por sempre me apoiarem em cada escolha que faço. Vocês são os meus exemplos de vida!

Aos meus irmão, Gabriel e Lucas, pelo amor, pela amizade e por serem tão presentes na minha vida. Sem vocês dois eu não conseguiria!

A Minha família que apesar da saudade diária se fazem tão presente na minha vida: Maria, Julia, Gian, Moreno, Carla, Delma.

A minha tia e madrinha Annamaria pelo amor e apoio.

A minha orientadora, Ângela Patrícia, pelos anos de convivência e por sempre acreditar em mim.

As minhas queridas amigas: Bia, Luiza, Mari, Naff, Raissa, Liginha, Julinha e Nina por sempre estarem presente em todos esses anos de Brasília e me apoiaram em tudo. Amo vocês sempre!

Aos amigos que a faculdade me deu e que levo para toda vida, Caio, Anne, Tata, Nina, Camilla, Ju, Irina, Zulu, Dayane, Gabriel, Marcelle.

Aos meus colegas de laboratório que tornaram essa dissertação muito mais leve e prazerosa: Narinha, Lailah, Margareti e Vivi.

Obrigada a CAPES pelo apoio financeiro e a FIOCRUZ pelo treinamento e ajuda para realização desta dissertação. 


\section{LISTA DE ILUSTRAÇÕES}

Figura 1 - Resultado da PCR para identificação dos sorotipos de Listeria monocytogenes isoladas de cortes cárneos e swabs de abatedouro frigorifico no Distrito Federal. 1) cepa de referência para o sorotipo $4 \mathrm{~b}$ oriunda da FIOCRUZ-RJ $(471 \mathrm{pb}$ e $597 \mathrm{pb})$; 2) cepa de referência para o sorotipo 1/2c oriunda da FIOCRUZ-RJ (691pb e 906pb); 3,4,6 e 7) fragmentos da dupla amplificação do fragmento de DNA lmo0737 (691 pb), sorogrupo IVb-V1 isoladas de cortes cárneos; 5) sorotipo 1/2c (691pb e 906pb); 8) 100 bp DNA ladder; 9) sorotipo 4b ( 471pb e $597 \mathrm{pb}$ ). Visualização em transiluminador Imagequant (Gelifesciences) em gel de agarose a $2 \%$ com concentração de $5 \mathrm{mg} / \mathrm{ml}$ de brometo de etídio.

Figura 2 - Perfis PFGE obtidos com a enzima de restrição ApaI (Roche Diagnostics) para as 13 cepas de L. monocytogenes isoladas em cortes cárneos bovino e swabs de ralo em abatedouro

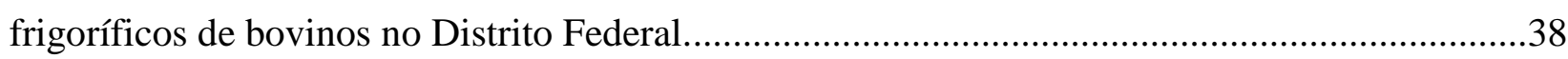




\section{LISTA DE TABELAS}

Tabela 1- Resultado da sorotipificação das 13 cepas de Listeria monocytogenes isoladas de cortes cárneos comercializados no Distrito Federal e swabs de ambiente oriundas de abatedouro

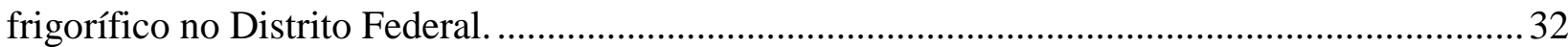

Tabela 2 - Teste de resistência antimicrobiana realizado em 13 cepas de Listeria monocytogenes isoladas de cortes cárneos bovinos comercializados no Distrito Federal e swabs de ambiente

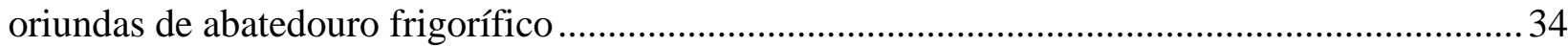




\section{LISTA DE ABREVIATURAS E SIGLAS}

\begin{tabular}{|c|c|}
\hline ABNT & Associação Brasileira de Normas Técnicas \\
\hline $\mathrm{BHI}$ & Caldo de infusão cérebro-coração \\
\hline $\mathrm{CDC}$ & Centers for Disease Control and Prevention \\
\hline CLSI & Clinical \& Laboratory Standarts Institute \\
\hline FDA & Food and Drug Administration \\
\hline LABENT & Laboratório de Enterobactérias \\
\hline LAMAL & Laboratório de Microbiologia dos Alimentos \\
\hline MAPA & Ministério da Agricultura, Pecuária e Abastecimento \\
\hline LEB & Listeria Enrichment Broth \\
\hline LPM & Lítio Feniletanol Moxalactam \\
\hline MOX & modified Oxford agar \\
\hline PCR & Polymerase Chain Reaction \\
\hline PFGE & Pulsed-field gel electrophoresis \\
\hline UVM & Universidade de Vermont Modificado \\
\hline USDA & United States Department of Agriculture \\
\hline
\end{tabular}




\section{SUMÁRIO}

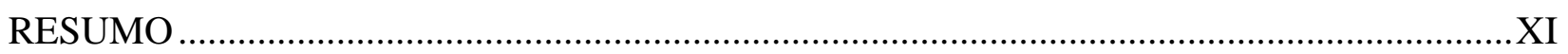

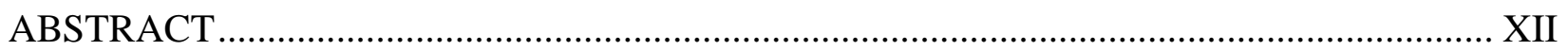

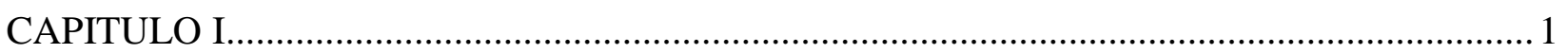

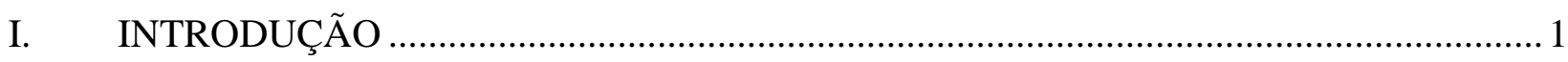

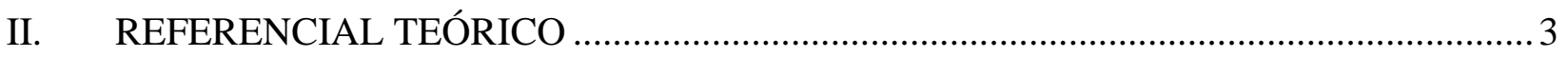

1. Caracterização do gênero ……………………………....................................................

2. Agente etiológico Listeria monocytogenes ....................................................................... 4

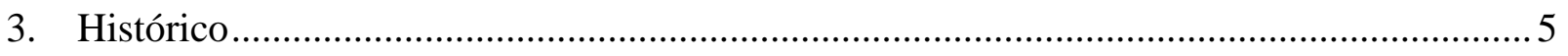

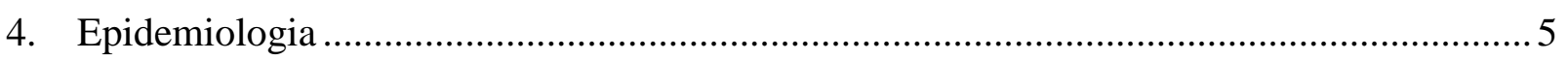

Distribuição geográfica ................................................................................................

5. Listeria monocytogenes e sua relação com alimentos de origem animal .............................. 6

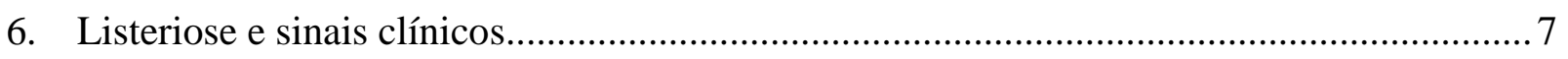

7. Métodos de detecção de L. monocytogenes ……………………………………............... 9

8. Resistencia aos antimicrobianos ................................................................................... 11

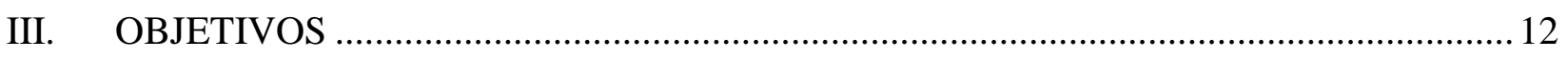

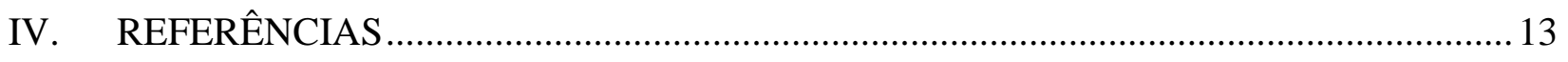

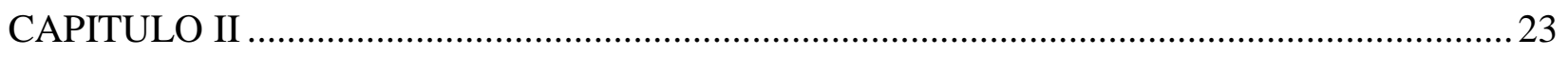

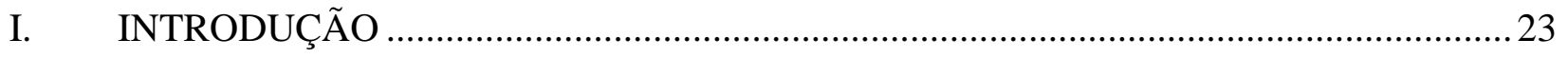

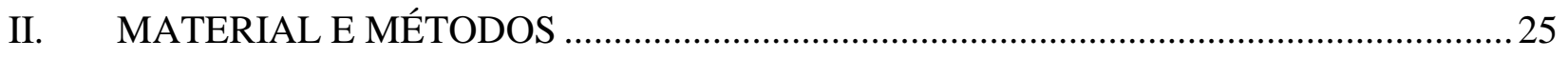

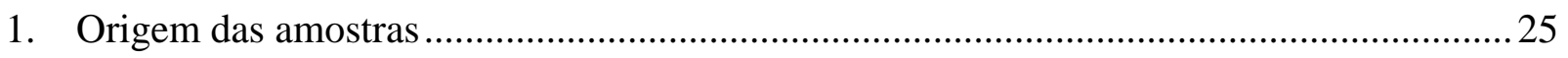

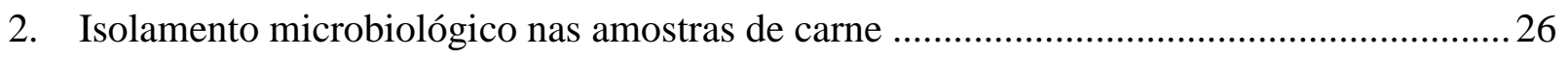




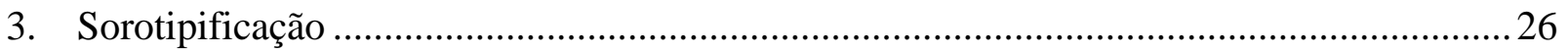

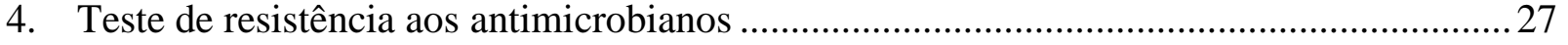

5. Eletroforese de campo pulsante (PFGE) .......................................................................2

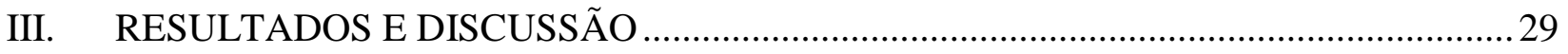

1. Isolamento microbiológico em amostras de cortes cárneos bovinos, swabs de carcaças bovinas e ambiente de abatedouros frigoríficos de bovinos localizados no Distrito Federal ....29

2. Sorotipificação pela técnica da reação em cadeia da polimerase em cepas de Listeria monocytogenes isoladas de cortes cárneos bovinos e ambientes de abatedouros frigoríficos...31

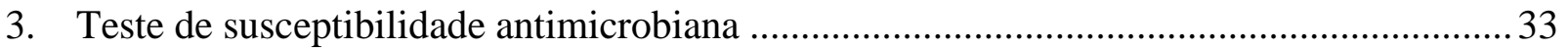

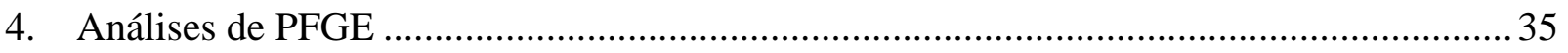

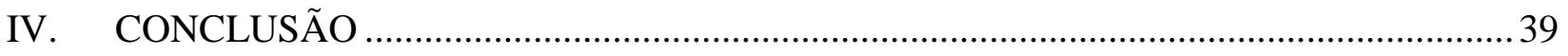

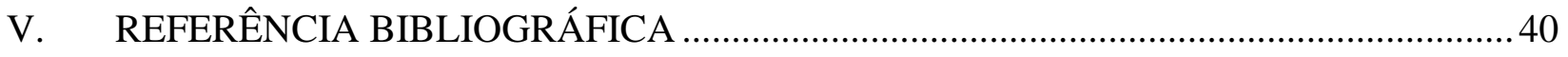




\section{RESUMO}

Este trabalho teve como objetivo realizar a detecção de cepas de Listeria monocytogenes de cortes cárneos bovinos bem como no ambiente de abatedouros frigoríficos localizados no Distrito Federal, promover a sorotipificação pela reação em cadeia da polimerase (PCR), realizar antibiograma e submeter às cepas à eletroforese de campo pulsado (Pulsed-field gel electrophoresis - PFGE). Foram analisados um total de 125 cortes cárneos bovinos, 45 amostras de swabs de carcaças bovinas e 43 amostras de swabs em que foram detectados um total de 13 cepas de Listeria monocytogenes, sendo 11 oriundas de cortes cárneos bovinos e duas cepas oriundas deswabs de ambiente em um abatedouro frigorifico. Não foram detectadas cepas de swabs de carcaça. Dentre as 13 cepas de Listeria monocytogenes foram encontradas seis cepas do sorotipo 4b, cinco do sorotipo 1/2c e duas cepas do sorotipo 1/2a. Dentre as 11 cepas de L. monocytogenes encontradas em cortes cárneos bovino, uma $(9,1 \%)$ cepa apresentou resistência a eritromicina, outra $(9,1 \%)$ cepa a gentamicina e outra a ciprofloxacina $(9,1 \%)$ e todas as cepas $(100 \%)$ apresentaram resistência ao Ácido Nalidíxico. Das duas (2) cepas oriundas de ralos de abatedouro frigorífico, todas (100\%) apresentaram resistência ao Ácido Nalidíxico e a sulfonamidas. A análise por eletroforese de campo pulsante (PFGE) demonstrou 8 diferentes pulsotipos, em que foram agrupados em 3 diferentes grupos clonais, que coincidentemente se correlacionavam com os 3 diferentes sorotipos encontrados sugerindo um ampla disseminação desses perfis no Distrito Federal. 


\title{
A MOLECULAR CHARACTERIZATION OF LISTERIA MONOCYTOGENES FROM BEEF
}

\section{SAMPLES AND CATTLE SLAUGHTERHOUSES LOCATED IN FEDERAL DISTRICT}

\begin{abstract}
The aim of the present work was the analysis of Listeria monocytogenes strains in beef samples as well as slaughterhouse environment, located in the Federal District, promote serotyping by polymerase chain reaction (PCR), perform antibiotic susceptibility and submit the strains to Pulsed-field gel electrophoresis (PFGE). A total of 125 beef samples were analyzed, 45 samples of carcasses swabs and 43 swab samples. It detected 13 strains of Listeria monocytogenes, 11 in beef samples. and 2 in slaughterhouse environmental. No carcass swabs strains were isolated. Among the 13 strains of Listeria monocytogenes, was found six strains of serotype 4b, five serotype 1/2c and two strains of serotype 1/2a. Among the 11 strains of Listeria monocytogenes found in beef, one $(9.1 \%)$ strain showed resistance to erythromycin, one $(9.1 \%)$ strain to gentamicin, one to ciprofloxacin $(9.1 \%)$ and all strains $(100 \%)$ were resistant to nalidixic acid. The two (2) strains coming from the slaughterhouse drains, all (100\%) were resistant to nalidixic acid and Sulfonamides. The analysis by pulsed field gel electrophoresis (PFGE) showed 8 different pulsotypes, they were grouped into three different clonal groups, which coincidentally correlated with the three different serotypes found, what suggests a widespread dissemination of these profiles in the Federal District.
\end{abstract}




\section{CAPITULO I}

\section{INTRODUÇÃ̃O}

O gênero Listeria compreende seis diferentes espécies, sendo Listeria grayi, Listeria innocua, Listeria ivanovii, Listeria monocytogenes, Listeria seeligeri e Listeria welshimeri (Scarcelli \& Piatti, 2002). Apenas a Listeria monocytogenes tem sido considerada patogênica para humanos e animais (DE VALK et al. 2005). O habitat natural destas bactérias são matérias vegetais em decomposição onde vivem como saprófitas (VASQUEZ-BOLAND et al. 2001). Ela pode ser encontrada naturalmente no solo, fezes dos animais, esgotos e na água (PAILLARD et al. 2003). A ampla distribuição dessa espécie no ambiente natural é provavelmente relacionada com sua habilidade em crescer e sobreviver em condições extremas, como em ambientes a temperatura de $4^{\circ} \mathrm{C}$. (MARGOLLES et al. 2001).

A doença causada pela Listeria monocytogenes em humanos é conhecida como listeriose. Este microrganismo é um bacilo intracelular facultativo, anaeróbios facultativos e Gram positivo e pode causar meningite ou meningoencefalite podendo levar o hospedeiro à morte em $30 \%$ dos casos (LECUIT, 2007). A associação recente da Listeria monocytogenes com doenças graves de origem alimentar sugere que a contaminação do alimento seja a principal forma de transmissão da listeriose humana. A listeriose acomete principalmente indivíduos imunossuprimidos, idosos, crianças e gestantes (FARBER \& PETERKIN, 1991; JERSEK, 1996). Neste último caso a listeriose pode resultar em aborto, parto pré-maturo, malformações no feto e infecção generalizada no recémnascido (LECUIT, 2007). Uma grande variedade de alimentos tem sido implicada em casos listeriose, como o leite e derivados, legumes e produtos cárneos de diferentes espécies de animais (GALLEGOS et al. 2008; VANEGAS et al., 2009). A Listeria monocytogenes pode entrar na cadeia alimentar durante todo o processo de abate dos animais, na ordenha ou contaminando o solo e vegetais com o uso de fertilizantes que possuem excretas de animais. (MCEWEN \& FEDORKACRAY, 2002). Uma vez presente nas fábricas de processamento de alimentos de origem animal, a bactéria do gênero Listeria dificilmente é eliminada da indústria; devido ao fato da grande capacidade dessa bactéria em formar biofilmes. (PARIZI, 1998). 
A resistência aos antibióticos usados para tratar a listeriose não é comumente encontrada. Mas devido a presença de tais resistências em outras bactérias, Doucet-Populaire et al. (1991) observaram que a emergência de resistência múltipla a antibióticos nesta espécie poderia ser secundária a aquisição de um plasmídeo auto-transferível originário de enterococos e estreptococos. No Brasil alguns estudos já foram feitos para conhecer o perfil de resistências para Listeria, como por exemplo, estudos feitos por Moreno et al. (2013) em ambientes de matadouros, na carne de porco e infecções humanas que já confirmaram o surgimento de cepas de Listeria resistentes a um ou mais antibióticos.

A caracterização microbiológica da Listeria monocytogenes pode ser realizada pela eletroforese em gel de campo pulsante (PFGE) com enzimas AscI e Apal (GRAVES E SWAMINATHAN, 2001; MARTIN et al. 2006), que por sua vez também é utilizado para soroagrupar e subtipar a Listeria monocytogenes, e é considerada o método padrão-ouro para analise devido ao seu alto poder discriminatório e de reprodutibilidade, atualmente é reconhecida como a mais importante técnica de tipificação para Listeria monocytogenes (WIEDMANN, 2002, GERNER-SMIDT et al. 2006, NEVES et al. 2008).

Tendo em vista a importância deste microrganismo para a saúde pública, aos poucos trabalhos já realizados no Distrito Federal e no país, este trabalho teve por objetivo realizar a detecção de cepas de Listeria monocytogenes de cortes cárneos bovinos bem como no ambiente de abatedouros frigoríficos localizados no Distrito Federal, promover a sorotipificação por PCR, realizar antibiograma, bem como submeter às cepas à eletroforese de campo pulsado (Pulsed-field gel electrophoresis - PFGE). 


\section{REFERENCIAL TEÓRICO}

\section{Caracterização do gênero}

A Listeria é composta por seis espécies: L. monocytogenes, L. seeligeri, L. ivannovii, L. innocua, L. welshimeri e L. grayi (LIU, 2006). Com exceção de L. grayi, todas as demais são encontradas em alimentos. De acordo com Leclercq et al. (2010) duas espécies (L. monocytogenes e L. ivanovii) são normalmente consideradas patogênicas para animais e seres humanos e a espécie considerada a principal causa de listeriose em humanos e animais é a L. monocytogenes. O gênero Listeria é composto por pequenos bacilos Gram-positivos, anaeróbicos facultativos, não formadores de esporos e que apresentam motilidade característica em formato de "guarda chuva" quando incubados entre 20 a $25^{\circ} \mathrm{C}$ (ROCOURT AND BUCHRIESER, 2007; SCHUCHAT et al. 1991). Seu crescimento ocorre em temperaturas que variam de $0,4^{\circ} \mathrm{C}$ até $50^{\circ} \mathrm{C}$ (FARBER \& PETERKIN, 1991), enquanto a maioria dos outros gêneros de bactéria não possuem essa característica (GANDHI \& CHIKINDAS, 2007).

O local mais comum para se encontrar a Listeria é o solo, água e também pode ser encontrada nas fezes dos animais e do homem, no leite das vacas, e em restos provenientes de abatedouros. Os ruminantes domésticos são considerados como reservatório desta bactéria, atuando como importante fonte de manutenção e disseminando o microrganismo no ambiente (VÁSQUEZBOLAND et al., 2001; NIGHTINGALE et al., 2004).

A classificação referente a bactérias do gênero Listeria spp. De acordo com Garrity et al. (2003) é descrita abaixo:

Domínio: Bactéria

Filo: Firmacutes

Classe: Bacilli

Ordem: Bacillales

Família: Listeriaceae

Gênero: Listeria

Espécies: Listeria monocytogenes, Listeria innocua, Listeria grayi, Listeria ivanovii, Listeria welshimeri e Listeria seeligeri. 


\section{Agente etiológico Listeria monocytogenes}

A Listeria monocytogenes se apresenta como bacilos Gram positivos e possui células que

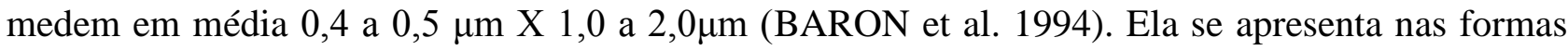
cocoides, e a aparência das colônias no ágar sangue pode levar a confusão com o Streptococcus beta hemolítico (QUINN et al. 1994). De acordo com Quinn et al. (1994) a Listeria monocytogenes é catalase positiva, oxidase negativa e expressa $\beta$-hemólise com a formação de zonas claras no ágar sangue.

A Listeria Monocytogenes pode ser classificada em dois (2) diferentes tipos de linhagens genéticas, a primeira (I) com os sorotipos $1 / 2 \mathrm{a}$, $4 \mathrm{~b}$ e $3 \mathrm{~b}$ encontrados normalmente em casos clínicos na listeriose humana. A segunda linhagem (II) representada pelos sorotipos 1/2a, 1/2c e 3 a no qual são obtidos principalmente em alimentos. NADON et al. (2001) e WARD et al. (2004) consideram também um terceiro grupo (III) em que estão presentes os sorotipos 4a e 4c, considerado raro de se encontrar, e podem ser encontrados em casos clínicos de listeriose em animais (GRAY et al. 2004; NORTON et al. 2001; FUGETT et al. 2007). Já Doumith et al. (2004) propuseram a reação em cadeia da polimerase (PCR) multiplex, em que utilizaram cinco conjuntos de primers para genes específicos que permitiram agrupar as cepas de Listeria monocytogenes em cinco diferentes grupos genéticos correlacionando com os sorotipos.

Esta bactéria é amplamente distribuída no ambiente, ela pode ser encontra tanto no solo, na água e nos esgotos (HOF, 2003). Ainda de acordo com Hof, (2003) ela já foi encontrada em 37 diferentes espécies de mamíferos e é provável que 1,0\% da população seja portadora desta bactéria no trato gastrointestinal. A elevada frequência de portadores saudáveis de L. monocytogenes, foram maiores entre os trabalhadores de abatedouros frigoríficos do que na média da população (NESBAKKEN et al., 1996). Diversos estudos já relacionaram a presença desta bactéria em amostras fecais de pessoas saudáveis como, por exemplo, Bojsen-Moller, (1972) e Lamont et al. (1986) reforçando o fato que o trato gastrointestinal humano é o reservatório da Listeria monocytogenes. 


\section{Histórico}

De acordo com Mantilla et al. (2007) o primeiro caso clínico de listeriose humana ocorreu em 1929, na Dinamarca, em que foi estabelecido a correlação entre a Listeria monocytogenes e a meningite em humanos e em 1981 em estudos feitos por Bem-Embarek, (1994), no Canadá, começou a suspeitar que a principal via da contaminação por Listeria monocytogenes em humanos era oriundas de alimentos. Este último foi considerado então o primeiro surto de listeriose de origem alimentar na América do Norte, em Nova Escócia no Canadá, com 41 doentes e 11 mortes. Este surto foi relacionado com a ingestão de salada contendo repolho contaminado a partir de adubo in natura proveniente de ovinos (SCHLECH III et al. 1983). Já de acordo com McLauchlin et al. (1991) o primeiro surto de listeriose relacionado com a ingestão de produtos cárneos contaminados, envolveu um tipo de patê importado pelo Reino Unido com 366 doentes e 63 mortes.

Em relação aos antimicrobianos, as primeiras cepas de Listeria monocytogenes resistentes aos antimicrobianos foram detectados em 1988 (POYART-SALMERON et al. 1990). Embora as cepas de Listeria monocytogenes com resistência a um ou mais antibióticos já tenham sido isoladas, como por exemplo, as cepas resistentes ao cloranfenicol, azitromicina, estreptomicina e tetraciclina (POYART-SALMERON et al. 1990).

\section{Epidemiologia}

\section{Distribuição geográfica}

A listeriose constitui uma doença de notificação compulsória na maioria dos países do mundo, e apesar de poucos registros oficiais de sua ocorrência, representa grande preocupação para as autoridades de saúde pública, uma vez que tem uma taxa alta de mortalidade e atinge preferencialmente pacientes com a imunidade baixa e gestantes (JEFFERS et al. 2001; ALLERBERGER et al. 2002; DOGANAY et al. 2003; DOUMITH et al. 2004). Todos os países nórdicos possuem um sistema de notificação laboratorial para Listeria monocytogenes. $\mathrm{Na}$ Finlândia, Noruega e Suécia os médicos obrigatoriamente devem relatar todos os casos diagnosticados de listeriose (GUDBJORNSDOTTIR et al. 2003). No Brasil, a legislação federal em 
vigor que contempla os Padrões Microbiológicos para alimentos está expressa na Resolução da Diretoria Colegiada (RDC) da Agencia Nacional de Vigilância Sanitária (ANVISA) do Ministério da Saúde, sob n ${ }^{\circ}$ 12, de 02/01/2001, em que explicita que a presença de Listeria monocytogenes deve estar ausente em uma amostra de $25 \mathrm{~g}$ de queijo. Para outros tipos de alimentos, não há limites fixados para esta bactéria (BRASIL, 2001). Entretanto a listeriose é relatada principalmente em países industrializados, e os casos notificados na África, Ásia e América do Sul ainda são baixos (ROCOURT et al. 2003).

Nos Estados Unidos (EUA) são confirmados 7,4 casos por milhão de habitante/ano de listeriose invasiva, 16 casos de listeriose perinatal a cada 100 mil nascimentos, sendo $23 \%$ responsáveis por morte fetal (CISTERNAS et al. 2002). De acordo com Wesley, (2009) também nos Estados Unidos (EUA) a Listeria monocytogenes é causadora de cerca de 2500 casos, 2289 hospitalizações e 449 mortes a cada ano com uma taxa de mortalidade de $28 \%$, por esses resultados esta bactéria vem sendo considerada um dos principais patógenos de origem alimentar. A incidência de listeriose no mundo varia entre 0,1 e 11,3 casos por milhão de habitantes por ano (SWAMINATHAN AND GERNER-SMIDT, 2007).

A dificuldade de recuperar organismos envolvidos nos surtos, a subnotificação e a demora na realização das análises convencionais são alguns dos importantes fatores que retardam ou impedem a notificação em situações de emergência (ARRUDA, 2007). Uma pesquisa realizada por Scavia et al. (2012) sobre pessoas com doença gastrintestinal aguda relataram que apenas 36,5\% procuraram assistência médica, e destes apenas 2,3\% tiveram uma amostra de fezes testada para investigação diagnóstica.

\section{Listeria monocytogenes e sua relação com alimentos de origem animal}

No Brasil, a ocorrência de Listeria spp. foi amplamente demonstrada em camarão (HOFER \& RIBEIRO, 1990), linguiça frescal (SILVA et al. 2004) de carne, leite e produtos lácteos (DESTRO et al., 1991; SILVA et al., 1998; GUDBJORNSDOTTIR et al. 2003; BARROS et al. 2007). 
Gandhi e Chikindas, (2007) ressaltaram que a contaminação dos produtos alimentícios pela Listeria pode ocorrer em qualquer fase de processamento, porém a contaminação do produto final, ou seja, depois de ser processado, é a principal causa de surtos. Gandhi e Chikindas, (2007) afirmam também que as principais fontes de contaminação por essa bactéria são alimentos crus, ingredientes não processados que são adicionados aos produtos processados, superfícies que entram em contato com o alimento, ambientes, manipulação imprópria do produto e acondicionamento inadequado. Martinez et al. (2003) e Rocourt et al. (2003) consideram que até 95\% dos casos de listeriose estão relacionados com o consumo de alimentos contaminados, especialmente produtos ready-to-eat. Já a presença de L. monocytogenes em carne bovina relada por Zhu et al. (2012) ocorre principalmente pela facilidade de contaminação desta bactéria durante todo o processamento em que já se tem o conhecimento de que o trato intestinal dos animais funciona como uma importante fonte de contaminação de carcaças e ambiente.

Gudbjornsdottir et al. (2003) encontraram em seu estudo 2,9\% cepas de Listeria monocytogenes em carnes cruas, 2,3\% cepas em produtos ready-to-eat, 8,3\% cepas em carne de frango cru e 13,5\% cepas em frutos do mar nos países nórdicos. Gudbjornsdottir et al. (2003) também relataram em seu estudo que a matéria prima crua que chegava na indústria estava menos contaminada do que o produto final no fim da linha de processamento da indústria e que a probabilidade do aumento de contaminação durante o processamento parece ser maior em peixes e aves, devido às maiores quantidades de água utilizada durante todo o processamento (GUDBJORNSDOTTIR et al. 2003). No Brasil, Mantilla et al. (2007) encontram em carne moída somente duas amostras (6,7\%), das 30 analisadas, contaminadas com L. monocytogenes. Em Portugal, Mena et al. (2004) das 17 amostras de carne bovina crua, três (17,7\%) foram positivas para L. monocytogenes.

\section{Listeriose e sinais clínicos}

A partir da década de 80, a listeriose se tornou uma doença de grande preocupação mundial devido ao diagnóstico de diversos casos de listeriose em humanos na Europa e nos Estados Unidos, em consequência da ingestão de alimentos contaminados (VASQUEZ-BOLAND et al. 2001). No Brasil sua notificação não é obrigatória e, portanto não há estatísticas oficiais para casos de 
listeriose no Brasil (HARTMANN et al. 2009). A presença de qualquer espécie de Listeria nos alimentos de origem animal é indicativa de condição higiênica deficiente em alguma etapa do processamento industrial, distribuição e ou armazenamento (LACIAR et al. 2006).

A associação recente da Listeria monocytogenes com doenças graves de origem alimentar sugere que a contaminação do alimento seja a principal forma de transmissão da listeriose humana. A maior parte dos casos desta doença em humanos ocorre em indivíduos imunossuprimidos, crianças e gestantes (JERSEK, 1998). A listeriose pode ter diferentes apresentações clínica tal como a septicemia, meningite e meningoencefalite. Em lactantes e mulheres grávidas a forma invasiva pode causar infecções perinatais e abortos espontâneos, respectivamente (SCHUCHAT et al. 1991;. VAZQUEZ-BOLAND et al., 2001; SIEGMAN-IGRA et al. 2002). A gastrenterite febril ocasionada por este patógeno geralmente é uma infecção autolimitada que afeta normalmente indivíduos saudáveis após a ingestão de produtos alimentares contaminados com uma grande carga da bactéria (OOI AND LORBER, 2005).

A presença de qualquer espécie de Listeria nos alimentos de origem animal é indicativa de condição higiênica deficiente em alguma etapa do processamento industrial, distribuição e ou armazenamento (LACIAR et al. 2006). Além disso, vale ressaltar que a Listeria monocytogenes, por ser encontrada em diferentes tipos de alimentos, pode causar severos quadros clínicos provocados a partir da ingestão de baixa dose infectante (ARRUDA, 2007). Condições sanitárias deficientes durante o abate dos animais, cozimento inadequado, armazenamento impróprio, e principalmente a falta de higiene durante todo o preparo dos produtos cárneos são condições que podem predispor o contato da bactéria com os indivíduos podendo assim levar a contaminação e tornarem-se portadores assintomáticos ou sintomáticos (GARRITY et al. 2003).

Os principais sinais clínicos observados em humanos em decorrência da listeriose são semelhantes ao de uma gripe comum, acompanhado de febre, dores musculares e alterações gastrointestinais. Em casos mais graves pode causar endocardite e ter uma taxa de mortalidade de até 50\% (VASQUEZ-BOLAND et al. 2001; DOGANAY, 2003; ARRUDA, 2007). Ainda de acordo com Arruda et al. (2007) e Vasquez-boland et al. (2001) é possível ocorrer a septicemia, aborto, parto prematuro e morte fetal em grávidas e em casos em que a bactéria atinge o sistema nervoso, pode ocasionar infecção do sistema nervoso central (VASQUEZ-BOLAND et al. 2001; ABRAM et al. 2003 ; DOGANAY, 2003; ARRUDA et al. 2007). 


\section{Métodos de detecção de L. monocytogenes}

Um dos métodos para isolamento da bactéria Listeria monocytogenes nos alimentos e preconizado pelo United States Department of Agriculture (USDA) consiste em uma fase de enriquecimento primário - em Caldo de enriquecimento da Universidade de Vermont Modificado (UVM), enriquecimento secundário - em caldo Fraser, plaqueamento seletivo, isolamento, purificação e caracterização bioquímica (realização com CAMP test, fermentação de açúcares e redução do nitrato), que é preconizada pela Instrução Normativa no 40 de 2005, do Ministério da Agricultura, Pecuária e Abastecimento - MAPA. Um segundo método preconizado pela United States Food and Drug Administration (FDA) inicia com o caldo de enriquecimento para Listeria (LEB) a $30^{\circ} \mathrm{C}$ por $24 \mathrm{~h}$ e $48 \mathrm{~h}$, depois pela semeadura de superfície em ágar Oxford (OXA) a $35^{\circ} \mathrm{C}$ por $48 \mathrm{~h}$ e por fim semeadura em ágar Cloreto de Lítio Feniletanol Moxalactam (LPM) a $30^{\circ} \mathrm{C} /$ por $24 \mathrm{~h}$ e $48 \mathrm{~h}$ (SILVA et al. 1997). Os métodos clássicos para detecção, contagem e identificação da Listeria monocytogenes são considerados efetivos, porém em relação ao controle de qualidade em indústrias elas são consideradas demoradas e dificultam a implementação de programas sanitários efetivos para garantir a qualidade microbiológica e atender assim a legislação vigente (BARBALHO, 2002). A disponibilidade de testes de diagnóstico rápido, específicos e sensíveis, capazes de distinguir $L$. monocytogenes de outras espécies de Listeria é essencial para o controle efetivo da doença (LIU, 2006).

Após o isolamento da Listeria se realizam diferentes testes bioquímicos como a catalase positiva, oxidase e indol negativo. A Listeria hidrolisa a esculina, porém não é capaz de hidrolisar a ureia. Além disso, entre as espécies de Listeria existem propriedades bioquímicas distintas que podem ser úteis para identificação. Como por exemplo, espécies de Listeria mostram variações significativas na sua capacidade de hemólise de glóbulos vermelhos de cavalo ou ovelha, e em sua capacidade de produzir ácido a partir de L-ramnose, D-xilose e $\alpha$-metil-D-manosídeo (ROBINSON et al. 2000; LIU, 2006).

A identificação da Listeria spp. e L. monocytogenes utilizando métodos moleculares está se tornando cada vez mais popular pois estas técnicas são extremamente precisas, sensíveis e específicas (GASANOV et al. 2005). A aplicação de técnicas moleculares facilitou também a 
identificação e caracterização de genes e proteínas associadas à virulência em L. monocytogenes (LIU, 2006). As ferramentas da biologia molecular, tais como a reação em cadeia da polimerase (PCR), também têm sido utilizadas para a realização de detecção direta deste microrganismo em alimentos de origem animal (DOUMITH et al. 2004; LIU, 2006). A PCR é uma técnica pela quais segmentos de DNA são amplificados utilizando uma polimerase estável ao calor e dois primers de DNA curtos (sequências iniciadoras específicas de parte de um gene específico) e os fragmentos amplificados são então detectados, normalmente utilizando a eletroforese em gel de agarose corada com brometo de etídio e as bandas são então visualizadas através de um transiluminador sob luz Ultravioleta (GASANOV et al. 2005).

A eletroforese de campo pulsante (Pulsed Field Gel Eletrophoresis - PFGE) devido à sua alta sensibilidade, alto poder discriminatório, padronização e reprodutibilidade, é atualmente reconhecido como a mais importante técnica de tipificação para Listeria monocytogenes e outros microrganismos (WIEDMANN, 2002). É uma técnica derivada da eletroforese convencional do DNA em gel de agarose, tendo como principal diferença, a mudança repetida da orientação do campo elétrico (TENOVER et al. 1995; HERSCHLEB et al. 2007). A análise em eletroforese de campo pulsante (Pulsed Field Gel Eletrophoresis - PFGE) é conhecida como padrão ouro para identificação de linhagens bacterianas, e tem sido utilizada para analisar variações genéticas dos microrganismos, bem como em cepas de Listeria monocytogenes (GALVÃO et al. 2012).. Uma endonuclease de restrição específica cliva enzimaticamente o DNA cromossômico em uma sequência específica de nucleotídeos. O número e o tamanho dos fragmentos gerados refletem a frequência e a distribuição destes sítios de restrição (DESTRO, 1995). Após a digestão, estes fragmentos de DNA bacteriano são separados por eletroforese, utilizando a PFGE. Após a coloração com brometo e visualização das bandas no gel, estas são analisadas em programas computacionais especializados, permitindo uma rápida e fácil comparação entre os perfis obtidos, os quais são agrupados em subtipos (AUTIO et al. 2002).

O PulseNet é uma rede internacional de subtipagem molecular, criada em 1996, para bactérias associadas à doenças de origem alimentar, desenvolvido e gerenciado pelo CDC (Centers for Disease Control and Prevention), dos Estados Unidos, que utiliza a PFGE como um método fundamental para a detecção de cepas e ajudar a definir focos que poderão possivelmente estar relacionadas a surtos (SPERRY et al., 2008). Quando os grupos de isolados com perfis de PFGE 
similares são detectados, os laboratórios de saúde pública que constituem o PulseNet, compartilham estes dados com epidemiologistas, os quais realizarão investigações sobre o histórico dos alimentos envolvidos no surto, de forma a traçar a origem do microrganismo e levantar a possibilidade de prevenir outros surtos e realizar melhorias nos sistemas de segurança alimentar (MONTVILLE \& MATTHEWS, 2005), é considerado então um instrumento importante para se analisar a circulação das cepas entre diferentes regiões e países.

\section{Resistencia aos antimicrobianos}

A Listeria monocytogenes é normalmente susceptível a inúmeros antibióticos (HOF et al. 1997), exceto para as cefalosporinas, fluoroquinolonas e fosfomicina (CHARPENTIER et al. 1999; POROS-GLUCHOWSKA et al. 2003). Porém à medida que os antimicrobianos vão sendo utilizados na criação de animais de produção em todo o mundo, o potencial de desenvolvimento de bactérias patogênicas resistentes transmitidas por alimentos aos antimicrobianos e subsequente transmissão para os seres humanos como contaminantes alimentares vem aumentando (MANTILLA et al. 2007; EFSA, 2008).

Além do mais, a mutação espontânea em bactérias de origem alimentar ou a propagação de bactérias resistentes na ausência de pressão seletiva pode também contribuir para o aumento da resistência antimicrobiana nos alimentos (EFSA, 2008b). Genes de resistência podem ser transferidos através de elementos genéticos móveis, tais como os transposons e os plasmídeos (POYART-SALMERON et al., 1990) para Listeria monocytogenes no interior do trato gastrintestinal (PERRETEN et al. 1997). Genes de resistência também podem vir de outras fontes

tais que esses genes frequentemente se movimentam entre bactérias Gram-positivas e Gramnegativas através da conjugação (CHARPENTIER et al. 1999). 


\section{OBJETIVOS}

\section{Objetivo geral}

- Realizar o isolamento das cepas de Listeria monocytogenes de cortes cárneos bovinos comercializados no Distrito Federal, de ambientes de abatedouros frigoríficos e de carcaças bovinas localizados no Distrito Federal.

\section{Objetivos específicos}

- Promover sorotipificação das cepas de Listeria monocytogenes isoladas por Reação em Cadeia de polimerase (PCR);

- Realizar o antibiograma nas cepas encontradas;

- Submeter às cepas à Eletroforese de Campo Pulsado (Pulsed-field gel electrophoresis PFGE). 


\section{REFERÊNCIAS}

ABRAM, M. SHLUTER, D., VUCKOVIC, D., WRABER, B. DORIC, M., DECKERT, M., Murine model of pregnancy-associated Listeria monocytogenes infection. FEM immunol med Microbiol 2003;35:117-82.

ALLERBERGER, F. Listeria: growth, phenotypic differentiation and molecular microbiology. FEMS Immunol. Med. Microbiol. 35, 183-189. 2003.

ANTUNES P., REU C., SOUSA J.C., PESTANA N., PEIXE L. Incidence and susceptibility to antimicrobial agents of Listeria spp and Listeria monocytogenes isolated from poultry carcasses in Porto, Portugal. J Food Prot 2002;65:1888-1893.

ARRUDA, G.A. Listeria e listeriose: perigo para as gestantes. Ed. Ponto Crítico, 2a ed., 143p., 2007.

AUTIO, T.; LUNDÉN, J.; FREDRIKSSON-AHOMAA, M.; BJÖRKROTH, J.; SJOBERG, A. M.; KORKEALA, H. Similar Listeria monocytogenes pulsotypes detected in several foods originating from different sources. International Journal of Food Microbiology, v. 77, p. 8390, 2002.

BARON, E.J.O.; PETERSON, L.R.; FINEGOLD, S.M. Bailey e Scott's. Diagnostic Microbiology. $9^{a}$ ed. Mosby, p. 458-460, 1994.

BEN-ENBAREK, P.K. Presence, Detection and Growth of Listeria monocytogenes in Seafoods. International Journal of Food Microbiology. v.23, p.17-34, 1994.

BOJSEN-MOLLER, J. Human listeriosis: diagnostic, epidemiologic and clinical studies. Acta Pathol. Microbiol. Scand. Sect. B Suppl. 229:72-92. 1972.

BRASIL. AGÊNCIA NACIONAL DE VIGILÂNCIA SANITÁRIA. (2001). Regulamento Técnico sobre Padrões Microbiológicos para Alimentos. Resolução - RDC 12, de 2 de janeiro de 2001. Diário Oficial da União, Brasília,10 de janeiro de 2001. Disponível em: 
http://portal.anvisa.gov.br/wps/wcm/connect/a47bab8047458b909541d53fbc4c6735/RDC_12_2 001.pdf?MOD=AJPERES acesso em: 13 jan 2016.

CHARPENTIER, E.; COURVALIN, P. Minireview: Antibiotic resistance in Listeria spp. Antimicrob. Agents Chemoter., 43(9), 2103-2108. 1999.

CHEN, M.; WU, Q.; ZHANG, J.; WU, S.; GUO, W. (2015) Prevalence, enumeration, and phenoand genotypic characteristics of Listeria monocytogenes isolated from raw foods in South China. Front. Microbiol. 6:1026. doi: 10.3389/fmicb.2015.01026

CISTERNAS A, LAGOS N, GALSTUCH J, GONZÁLEZ C, GARCÍA C, DÍAZ J. Infección por Listeria monocytogenes y embarazo con buen resultado perinatal. Rev Chil Obstet Ginecol 2002; 67: 237-41.

DESTRO, M. T., SERRANO, A. M., KABLIKI, D. Y. Isolation of Listeria species from some Brazilian meat and dairy products. Food Control, 2, 110-112(1991).

DESTRO, M. T. Listeria monocytogenes em camarão (Penaeus brasiliensis): marcadores sorológicos e genéticos no monitoramento de sua disseminação em uma unidade processadora de pescado. Tese de doutorado. Curso de Pós-Graduação em Ciências dos alimentos, Área de Bromotologia/USP, 1995.

DOGANAY M. Listeriosis: clinical presentation FEMS Immunol. Med. Microbiol., 1485 (2003), pp. 1-3

DOUCET-POPULAIRE, F., TRIEU-CUOT, P., DOSBAA, I., ANDREMONT, A., COURVALIN, P. Inducible Transfer of Conjugative Transposon Tn1545 from Enterococcus faecalis to Listeria monocytogenes in the Digestive Tracts of Gnotobiotic Mice. Antimicrobial agents and chemotherapy, Jan. p. 185-187. 1991.

DOUMITH, M.; BUCHRIESER, C.; GLASER, P.; JACQUET, C.; MARTIN, P. Differentiation of the major Listeria monocytogenes serovars by multiplex PCR. Journal of Clinical Microbiology, v.42, n.8, p.3819-3822, 2004.

EFSA (European Food Safety Authority). Draft Opinion on Antimicrobial Resistance in Food. 2008a. 
EFSA (European Food Safety Authority). Scientific Opinion of the Panel on Biological Hazards on a request from the Health and Consumer Protection, Directorate General, European Commission on Microbiological Risk Assessment in feedingstuffs for foodproducing animals. The EFSA Journal (2008) 720, 1-84. 2008b.

FARBER, J., PETERKIN, P. Listeria monocytogenes, a food-borne pathogen. Microbiol. Rev, 55:476-511. 1991.

FILIOUSIS, G.; JOHANSSON, A.; FREY, J.; PERRETEN, V. Prevalence, genetic diversity and antimicrobial susceptibility of Listeria monocytogenes isolated from open-air food markets in Greece. Food Control, v. 20, p. 314-317, 2009

FUGETT, E.B., SCHOONMAKER-BOPP, D., DUMAS, N.B.,CORBY, J. AND WIEDMANN, M. Pulsed-Field Gel Electrophoresis (PFGE) analysis of temporally matched listeria monocytogenes isolates from human clinical cases, foods, ruminant farms, and urban and natural environments reveals source-associated as well as widely distributed PFGE Types. J Clin Microbiol 45,865-873. 2007

FRANCIOSA, G.; TARTARO, S.; NEERGAARD, W.; AURELI, P. Caracterization of Listeria monocytogenes Strains Involved in Invasive and Noninvasive Listeriosis Outbreaks by PCRBased Fingerprinting Techniques. Applied and Environmental Microbiology. 2001. v.67, n.4, p. 1793-1799.

GANDHI, M.; CHIKINDAS, M.L. Listeria: A foodborne pathogen that knows how to survive. Int. J. Food Microbiol., v.113, p.1-15, 2007.

GALLEGOS J.M; VANEGAS M.C; ALBARRACI’N Y, MATTAR S; POUTOU R.A; CARRASCAL A.K. Frequency of isolation of Listeria spp., in different retail foods in Colombia. APRA 2008;4:9-18.

GARRITY, G.M.; BEM, J.A.; LILBURN, T.G. Taxonomic outline of Procaryotes. Bergey's Manual of Systematic Bacteriology. 2a ed. Michigan - Science, p. 102-103, 2003.

GASANOV, U., HUGHES, D., HANSBRO, P.M. Methods for the isolation and identification of Listeria spp. and Listeria monocytogenes: a review. FEMS Microbiol Rev 29:851-875. (2005).

GERMANO \& GERMANO, Higiene e Vigilância Sanitária de Alimentos. São Paulo: Varela, 2008. 
GRAY, M. J., R. N. ZADOKS, E. D. FORTES, B. DOGAN, S. CAI, Y. CHEN, V. N. SCOTT, D. E. GOMBAS, K. J. BOOR, AND M. WIEDMANN. Listeria monocytogenes isolates from foods and humans form distinct but overlapping populations. Appl. Environ. Microbiol. 2004. 70:5833-5841.

GRAVES, L.M., SWAMINATHAN, B. PulseNet standardized protocol for subtyping Listeria monocytogenes by macrorestriction and pulsed-field gel electrophoresis. International Journal of Food Microbiology. 2001.65, 55-62.

HARTMANN, W., ANDRADE, U. V. C., STEFFENS, M. B. R., HARTMANN, M. S., KADOWAKI, M. A. S., MASSON, M. L. Qualidade microbiológica do leite cru produzido na região oeste do paraná e ocorrência de Listeria monocytogenes. ARS VETERINARIA, Jaboticabal,SP ,v.25, n.2, 072-078, 2009.

HALPIN, JESSICA L., GARRETT, NANCY M., RIBOT, EFRAIN M., GRAVES, LEWIS M., COOPER, KARA L. Re-evaluation, Optimization, and Multilaboratory Validation of the PulseNet-Standardized Pulsed-Field Gel Electrophoresis Protocol for Listeria monocytogenes. Foodborne pathogens and disease Volume 7, Number 3, 2010.

HERSCHLEB, J.; ANANIEV, G. \& SCHWARTZ, D. C. Pulsed-field gel electroforesis. Nature Protocols, v. 2, n. 3, 2007.

HOFER, E., \& RIBEIRO, R. Ocorrência de espécies de Listeria em camarão industrializado. Revista de Microbiologia, 21(2), 207-208. (1990).

HOF, H., T. NICHTERLEIN, AND M. KRETSCHMAR. Management of listeriosis. Clin. Microbiol. 1997. Rev. 10:345-357.

HOF, H. Therapeutic options. FEMS imunnol Med Microbiol 2003; 35:203-05

HUNTER, S. B.; VAUTERIN, P.; LAMBERT-FAIR, M. A.; M. DUYNE, S.V.; KUBOTA, K.; GRAVES, L.; WRIGLEY, D,: BARRETT, T. and RIBOT, E. Establishment of a Universal Size Standard Strain for Use with the PulseNet 75 Standardized Pulsed-Field Gel Electrophoresis Protocols: Converting the National Databases to the New Size Standard. Journal of Clinical Microbiology, v. 43, n. 3, p. 1045-1050, 2005. 
JEFFERS, G. T., BRUCE, J. L., MCDONOUGH, P., SCARLETT, J., BOOR, K. J. \& WIEDMANN, M. Comparative genetic characterization of Listeria monocytogenes isolates from human and animal listeriosis cases. Microbiology 147, 1095-1104. 2001.

JERSEK, B.; GILOT, P.; GUBINA, M.; KLUN, N.; MEHLE, J.; TCHERNEVA, E.; RIJPENS, N.; HERMAN, L. Typing of Listeria monocytogenes Strains by Repetitive Element SequenceBased PCR. Journal of Clinical Microbiology. 1999. v.37, p.103-109.

JERSEK, B.; TCHERNEVA, E.; RIJPENS N.; HERMAN, L. Repetitive Element Sequence-Based PCR for Species and Strain Discrimination in the Genus Listeria. Letters in Applied Microbiology, Vol. 23, No. 1, 1996, pp. 55-60

KEROUANTON, A.; BRISABOIS, A.; DENOYER, E.; DILASSER, F.; GROUT, J.; SALVATD, G.; PICARD, B. Comparison of five typing methods for the epidemiological study of Listeria monocytogenes. International Journal of Food Microbiology, v. 43, p. 61-71, 1998.

LACIAR, L.; VACA, R.; LOPRESTI, A. DNA Fingerprinting by ERIC-PCR for Comparing Listeria spp. Strains Isolated from Different Sources in San Luis, Argentina. Revista Argentina de Microbiologia, 2006. v.38, p.55-60.

LAMONT, R. J., AND R. POSTLETHWAITE. Carriage of Listeria monocytogenes and related species in pregnant and nonpregnant women in Aberdeen, Scotland. J. Infect. 13:187-193. 1986.

LECUIT, M. Human Listeriosis and Animal Models. Microbes and Infeccion. v.9, p.1216-1225, 2007.

LEClerCQ, A., Clermont, D., BIZET, C., GRIMONT, P. A. D., FleChE-MATÉOS, A., ROCHE, S. M. , BUCHRIESER, C., CADET-DANIEL, V., MONNIER, A., LECUIT, M., ALLERBERGER, F. Listeria rocourtiae sp. nov. International Journal of Systematic and Evolutionary Microbiology, 60, 2210-2214. 2010

LIU, D. Identification, subtyping and virulence determination of Listeria monocytogenes, an important fodborne pathogen. J. Med. Microbiol., v.55, p.645-659, 2006. 
MANTILlA, S.P.S.; FRANCO, R.M.; OLIVEIRA, L.A.T.; SANTOS, E.B.;GOUVÊA, R. Importância da Listeria monocytogenes em Alimentos de Origem Animal. Revista da FZVA. v.14, n.1, p.180-192, 2007.

MARGOLLES, A., B. MAYO, AND C.G. DE LOS REYES-GAVILAN. Susceptibility of Listeria monocytogenes and Listeria innocua strains isolated from short-ripened cheeses to some antibiotics and heavy metal salts. Food Microbiol. 2001.18:67-73.

MARTINEZ, I., RORVIK, L.M., BROX, V., LASSEN, J., SEPPOLA, M., GRAM, L. AND FONNESBECH-VOGEL, B. Genetic variability among isolates of Listeria monocytogenes from food products, clinical samples and processing environments, estimated by RAPD typing. Int. J. Food Microbiol. 84, 285-297. 2003.

MARTIN, P., JACQUET, C., GOULET, V., VAILlANT, V., DE VALK, H. Pulsed-field gel electrophoresis of Listeria monocytogenes strains: the PulseNet Europe Feasibility Study. Foodborne Pathogens and Disease 3, 2006. 303-308.

MCEWEN, S. A. FEDORKA-CRAY, P. J. Antimicrobial use and resistance in animals. Clin, Infect. Dis, 2002. 34(suppl 3): S93-S106.

MCLAUCHLIN, J., HALL, S., VELANI, S., GILBERT, R. Human listeriosis and paté: a possible association. BMJ: British Medical Journal 303, 773. 1991.

MENA, C., AlMEIDA, G., CARNEIRO, L., TEIXEIRA, P., HOGG, T., GIBBS, P.A. Incidence of Listeria monocytogenes in different food products commercialized in Portugal. Food Microbiology, Amsterdam, v. 21, p. 213-216, 2004.

MONTEVILLE, T. J., MATHEWS, K. Food Microbiology: an introduction. ASM Press, American Society for Microbiology, 2005

NADON, C. A., D. L. WOODWARD, C. YOUNG, F. G. RODGERS, AND M. WIEDMANN. Correlations between molecular subtyping and serotyping of Listeria monocytogenes. J. Clin. Microbiol. 2001. 39:2704-2707.

NESBAKKEN, T., Listeria monocytogenes in the Food Chain-A Foodborne Infection Problem Common to the Nordic Countries. The Nordic Council of Ministers, No. 635, TemaNord, p. 48. 1995. 
NEVES, E., LOURENÇO, A., SILVA, A.C., COUTINHO, R., BRITO, L. Pulsed-field gelelectrophoresis (PFGE) analysis of Listeria monocytogenes isolates from different sources and geographical origins and representative of the twelve serovars. Systematic and Applied Microbiology 31 387-392. 2008.

NIGHTINGALE, K.K., Y.H. SCHUKKEN, C.R. NightinGALE, FORTES, E. D., HO, A. J., HER, Z., GROHN, Y.T., MCDONOUGH, P.L., WIEDMANN, M. Ecology and transmission of Listeria monocytogenes infecting ruminants and in the farm environment. Appl. Environ. Microbiol. 70:4458-4467. 2004.

NORTON, D. M., J. M. SCARLETT, K. HORTON, D. SUE, J. THIMOTHE, K. J. BOOR, AND M. WIEDMANN. Characterization and pathogenic potential of Listeria monocytogenes isolates from the smoked fish industry. Appl. Environ. Microbiol. 2001. 67:646-653.

OOI S.T., LORBER B. Gastroenteritis due to Listeria monocytogenes. Clin Infect Dis. 40(9):132732. 2005

OKWUMABUA, O.; O’CONNOR, M.; SHULL, E.; STRELOW, K.; HAMACHER, M.; KURZYNSKI, T.; WARSHAUER, D. Characterization of Listeria monocytogenes Isolates from Food Animal Clinical Cases: PFGE Pattern Similarity to Strains from Human Listeriosis Cases. FEMS Microbiology Letters, 2005.Vol. 249, No. 2, pp. 275-281.

PAILlARD, D., DUbOIS, V., DURAN, R., NATHIER, F., GUitTET, C., CAUMETTE, P., QUENTIN, C. Rapid identification of Listeria species by using restriction fragment length polymorphism of PCR-amplified 23S rRNA gene fragments. Applied and environmental microbiology, nov., p. 6386-6392, 2003.

PERreten, V., SChWARZ, F., CRESTA, L., BOEGlin, M., DASEN, G., TEUbER, M., Antibiotic resistance spread in the food. Nature 389, 801-802, 1997.

POROS-GLUCHOWSKA, J.; MARKIEWICZ, Z. Antimicrobial resistance of Listeria monocytogenes. Acta Microbiol. Pol., 52(2), 113-129. 2003.

POYART-SALMERON C, TRIEU-CUOT P, CARLIER C, MACGOWN A, MCLAUCHLIN J, COURVALIN P. Genetic basis of tetracycline resistance in clinical isolates of Listeria monocytogenes. Antimicrob Agents Chemother 1992;36:463-466. 
QUINN, P.J.; CARTER, M.E.; MARKEY, B.; CARTER, G.R. Clinical veterinary microbiology. $1^{\text {a }}$ ed. Spain - Mosby-Year Book Europe Limited, p. 170-174, 1994.

ROBINSON, R. K., BATT, C. A., PATEL, P. D. Encyclopedia of Food Microbiology. San Diego, CA: Academic Press. 2000.

ROCOURT, J., BENEMBAREK, P., TOYOFUKU, H., SCHLUNDT, J. Quantitative risk assessment of Listeria monocytogenes in ready-to-eat foods: the FAO/ WHO approach, FEMS Immunol. Med. Microbiol. 35 (2003) 263e267.

SCAVIA, G., BALDINELLI, F., BUSANI, L., CAPRIOLI, A. The burden of self-reported acute gastrointestinal illness in Italy: a retrospective survey, 2008-2009. Epidemiol. Infect. 140, 1193-1206. 2012.

SILVA, M. C. D., HOFER, E., \& TIBANA, A. Incidence of Listeria monocytogenes in cheese produced in Rio de Janeiro, Brazil. Journal of Food Protection, 61(3), 354-356 . (1998).

SWAMINATHAN, B., GERNER-SMIDT, P. The epidemiology of human listeriosis. Microbes Infect. Inst. Pasteur 9, 1236-1243. 2007.

ROCOURT, J., BUCHRIESER, C. The genus Listeria and Listeria monocytogenes: phylogenetic position, taxonomy, and identification. In Listeria, Listeriosis, and Food Safety, 3rd edn, pp. 120. Edited by E. T. Ryser \& E. H. Marth. Boca Raton, FL: CRC Press. 2007.

ROTA C, YANGUELA J, BLANCO D, CARRAMINANA JJ, ARINO A, HERRERA A. High prevalence of multiple resistance to antibiotics in 144 Listeria isolates from Spanish dairy and meat products. J Food Prot 1996;59:938-943.

SCARCELLI, E.; PIATTI, R.M. Patógenos Emergentes Relacionados à Contaminação de Alimentos de Origem Animal. Instituto Biológico. 2002. v.64, n.2, p.123-127.

SHEN, Y.; LIU, Y.; ZHANG, Y.; CRIPE, J.; CONWAY, W.; MENG, J.; HALL, G.; BHAGWAT, A.A. Isolation and Characterization of Listeria monocytogenes Isolates from Ready-To-Eat Foods in Florida. American Society for Microbiology. 2006. v.72, n.7, p. 5073-5076.

SCHUCHAT, A., SWAMINATHAN, B., BROOME, C.V. Epidemiology of human listeriosis. Clinical Microbiology Reviews 4 169-183. 1991. 
SCHLECH III, W.F., LAVIGNE, P.M., BORTOLUSSI, R.A., ALLEN, A.C., HALDANE, E.V., WORT, A.J., HIGHTOWER, A.W., JOHNSON, S.E., KING, S.H. Epidemic listeriosis-evidence for transmission by food. New England Journal of Medicine 308, 203-205. 1983.

SIEGMAN-IGRA, Y., R. LEVIN, M. WEINBERGER, Y. GOLAN, D. SCHWARTZ, Z. SAMRA, H. KONIGSBERGER, A. YINNON, G. RAHAV, N. KELLER, N. BISHARAT, J. KARPUCH, R. FINKELSTEIN, M. ALKAN, Z. LANDAU, J. NOVIKOV, D. HASSIN, C. RUDNICKI, R. KITZES, S. OVADIA, Z. SHIMONI, R. LANG, T. SHOHAT. Listeria monocytogenes infection in Israel and review of cases worldwide. Emerg. Infect. Dis. 8:305-310, 2002.

SILVA, W.P., LIMA, A.S., GANDRA, E.A. ARAÚJO, M.R., MACEDO, M.R.P., DUVAL, E.H. Listeria spp. no processamento de linguiça frescal em frigoríficos de Pelotas, RS, Brasil. Ciência Rural, Santa Maria, v.34, n.3, p.911-916, mai-jun, 2004

SPERRY, K. E. V.; SOPHIA KATHARIOU, S.; EDWARDS, J. S. and WOLF, L. A. Multiple Locus Variable-Number Tandem-Repeat Analysis as a Tool for Subtyping Listeria monocytogenes Strains. Journal of Clinical Microbiology, v. 46, n. 4, p. 1435-1450, 2008.

SWAMINATHAN, B., BARRETT, T.J., HUNTER, S.B., TAUXE, R.V., 2001. PulseNet: the molecular subtyping network for foodborne bacterial disease surveillance, United States. Emerging Infect. Dis. 7, 382 - 389.

TENOVER, F. C.; ARBEIT, R. D.; GOERING, R. V.; MICKELSEN, P. A.; MURRAY, B. M.; PERSING, D. H. and SWAMINATHAN, B. Interpreting Chromosomal DNA Restriction Patterns Produced by Pulsed-Field Gel Electrophoresis: Criteria for Bacterial Strain Typing. Journal of Clinical Microbiology, v. 33, n. 9, p. 2233-2239, 1995.

THÉVENOT, D.; DELIGNETTE-MULLER, M.-L.; CHRISTIEANS, S.; LEROY, S.; KODJO, A.; VERNOZY-ROZAND, C. Serological and molecular ecology of Listeria monocytogenes isolates collected from 13 French pork meat salting-curing plants and their products. International Journal of Food Microbiology, v. 112, p. 153-161, 2006.

TRABULSI, L.R.; ALTHERTHUM, F.; GOMPERTZ, O.F.; CANDEIRAS, J.A.N. Microbiologia. São Paulo: Atheneu, 3.ed., 1999. 586p. 
VANEGAS M.C; VASQUEZ E; MARTINEZ A.J; AND RUEDA A.M. Detection of Listeria monocytogenes in raw whole milk for human consumption in Colombia by real-time PCR. Food Cont 2009;20:430-432.

VÁSQUEZ-BOLAND, J.A.; KUHN, M.; BERCHE, B.; CHAKRABORTY, T.; DOMÍNGUEZBERNAL, G.; GOEBEL, W.; GONZÁLEZ-ZORN, B.; WEHLAND, J.; KREFT, J. Listeria Pathogenesis and Molecular Virulence Determinants. Clinical Microbiology Reviews. 2001. v.14, n.3, p. $584-640$.

WARD, T. J., L. GORSKI, M. K. BORUCKI, R. E. MANDRELL, J. HUTCHINS, AND K. PUPEDIS. . Intraspecific phylogeny and lineage group identification based on the prfA virulence gene cluster of Listeria monocytogenes. J. Bacteriol. 2004. 186:4994-5002.

WALSH D., DUFFY G., SHERIDAN J. J., BLAIR I. S., AND MCDOWELL D.A. Antibiotic resistance among Listeria, including Listeria monocytogenes, in retail foods. J Appl Microbiol 2001;90:517-522

WESLEY, I. Public health impact of food-borne illness: impetus for the international food safety effort. In N. Heredia, I. Wesley, \& S. Garcia (Eds.), Microbiologically safe foods (pp. 3e13). United States of America: Wiley, A John Wiley \& Sons, Inc. (2009).

WIEDMANN, M. Molecular Subtyping Methods for Listeria monocytogenes. Journal of AOAC International, 2004. v. 85, n. 2, 2002.

ZHU, L., FENG, X., ZHANG, L., ZHU, R., LUO, X. Prevalence and Serotypes of Listeria monocytogenes Contamination in Chinese Beef Processing Plants. Foodborne Pathogens and Disease 9, 556-560. 2012. 


\section{CAPITULO II}

\section{INTRODUÇÃO}

O gênero Listeria é um patógeno intracelular facultativo, Gram positivo e compreende seis diferentes espécies: Listeria grayi, Listeria innocua, Listeria ivanovii, Listeria seeligeri, Listeria welshimeri e Listeria monocytogenes. Destas espécies apenas a ultima é descrita como patogênica para humanos (SCARCELLI \& PIATTI, 2002). A doença causada por este tipo de bactéria é denominada listeriose e é veiculado principalmente por alimento (LECUIT, 2007; GALLEGOS et al. 2008; VANEGAS et al. 2009). Ela possui 13 sorotipos, dentre esses, quatro sorotipos (4b, 1/2a, $1 / 2$ b e 1/2c) são responsáveis por mais de $95 \%$ dos casos de listeriose em humanos (CARTWRIGHT et al. 2013).

A Listeria monocytogenes normalmente é sensível à maioria dos antibióticos exceto a cefalosporinas e fosfomicina, a que são naturalmente resistentes (TROXLER et al. 2000). Mas à medida que os antimicrobianos vão sendo utilizados na criação de animais de produção em todo o mundo, existe um interesse global referente ao aumento do número de bactérias resistentes às drogas (MANTILLA et al. 2007). No Brasil alguns estudos já foram feitos para conhecer o perfil de resistências para Listeria, como por exemplo, estudos feitos por Moreno et al. (2013) em ambientes de matadouros, carne de porco e infecções humanas que já confirmaram o surgimento de cepas de Listeria resistentes a um ou mais antibióticos.

A caracterização microbiológica da Listeria monocytogenes pode ser realizada pela determinação do sorogrupo (SEELIGER \& HÖHNE, 1979; DOUMITH et al. 2004; CHEN \& KNABEL et al. 2007; KEROUANTON et al. 2010; ) e também pela eletroforese em gel de campo pulsante (PFGE) com enzimas AscI e Apal (GRAVES \& SWAMINATHAN, 2001; MARTIN et al. 2006), que por sua vez é considerado o método padrão ouro para subtipagem e atualmente é reconhecida como a mais importante técnica de tipificação para Listeria monocytogenes (WIEDMANN, 2002),devido ao seu alto poder discriminatório, reprodutibilidade e padronização (GERNER-SMIDT et al. 2006). Após as análises das bandas em programas computacionais especializados, o PFGE permite uma rápida e fácil comparação entre os perfis obtidos, os quais são agrupados em pulsotipos (AUTIO et al. 2002). Essa técnica também pode permitir a identificação 
de pulsotipos específicos que não puderam ser diferenciados previamente pela sorotipificação (BORUCKI et al. 2004). No Brasil há relatos da utilização desta técnica em cepas de Listeria monocytogenes detectadas em diferentes tipos de alimentos bem como em casos clínicos (GALVÃO et al. 2012; BARBOSA et al. 2015; CAMARGO et al. 2015), porém no Distrito Federal essa técnica em cepas de Listeria ainda é pouco usada, restringindo-se à cepas oriundas de casos clínicos.

Levando-se em consideração a relevância deste microrganismo para a saúde pública, aos poucos trabalhos realizados com Listeria no Distrito Federal oriundas de alimentos e indústrias de alimentos de origem animal, este trabalho teve por objetivo realizar a detecção de cepas de Listeria monocytogenes de cortes cárneos bovinos bem como no ambiente de abatedouros frigoríficos localizados no Distrito Federal, promover a sorotipificação por PCR, realizar antibiograma, bem como submeter às cepas à eletroforese de campo pulsado (Pulsed-field gel electrophoresis - PFGE). 


\section{MATERIAL E MÉTODOS}

\section{Origem das amostras}

Foram analisadas um total de 125 cortes cárneos bovinos, que foram obtidas junto aos estabelecimentos comerciais, em que se simulou uma situação real de compra do consumidor, atentando para embalagens íntegras e com selo de inspeção veterinária federal. Quarenta e cinco (45) amostras de swabs de meias carcaças bovinas, sendo 15 obtidas anteriormente à etapa da lavagem final para resfriamento, 15 obtidos logo após a lavagem final e 15 após 24 horas de permanência em câmara de resfriamento de carcaças. Os locais escolhidos para a obtenção dos swabs nas meias carcaças foram realizados segundo os protocolos descrito por Jardim et al. (2006), em que foram demarcadas com moldes estéreis confeccionados de aço inoxidável com área delimitada de $10 \mathrm{~cm}^{2}$ (um molde para cada ponto). Foram considerados três locais para a coleta das amostras sem meias carcaças bovinas: região do coxão, lombo e ponta de agulha. Os swabs foram obtidos conforme a Associação Brasileira de Normas Técnicas - ABNT (1988), realizando a técnica de esfregaço de superfícies em meias carcaças com auxílio de swabs com ponta em algodão hidrófilo esterilizados. Após a aplicação nos três pontos estudados, os mesmos foram introduzidos em tubos contendo $20 \mathrm{~mL}$ de água peptonada a $0,1 \%$ (solução de transporte). Foram obtidos quarenta e três (43) amostras de swabs de ambientes em abatedouros frigoríficos de bovinos, sendo 14 amostras oriundas da parede da câmara frigorífica, 11 amostras de swabs de ralos de escoamento localizados dentro dos abatedouros frigoríficos, 10 da mesa de inspeção e 8 amostras de swabs oriundos dos pisos de uma única sala de abate. A técnica utilizada para colheita de amostras foi a do esfregaço de superfície com swabs em água peptonada $1 \%$ e utilizando moldes estéreis de $10 \mathrm{~cm}^{2}$ (ABNT, 1988).

Todas as amostras foram acondicionadas em caixas isotérmicas e encaminhadas ao laboratório de microbiologia dos alimentos (LAMAL), da Faculdade de Agronomia e Medicina Veterinária da Universidade de Brasília para as análises. 


\section{Isolamento microbiológico nas amostras de carne}

A metodologia de isolamento microbiológico utilizada foi a descrita pela Instrução Normativa n ${ }^{\circ} 40$ de 2005, do Ministério da Agricultura, Pecuária e Abastecimento - MAPA (Brasil, 2005), bem como a descrita por Silva et al. (1997), em que $25 \mathrm{~g} \pm 1,0 \mathrm{~g}$ das amostras de carne bovina foram pesadas em sacos de homogeneização estéreis, sendo adicionados $225 \mathrm{~mL}$ de caldo UVM (Acumedia ( )para incubação a $30^{\circ} \mathrm{C} \pm 2^{\circ} \mathrm{C}$ por 24 horas. Em seguida, transferiu-se $0,1 \mathrm{~mL}$ do caldo UVM para $10 \mathrm{ml}$ de caldo Fraser (Acumedia ${ }^{\circledR}$ ) que foram incubados a $35^{\circ} \mathrm{C}$ por $26 \mathrm{~h}$ e por fim distribuiu-se $0,1 \mathrm{~mL}$ do caldo Fraser, que apresentava hidrólise da esculina, para uma placa de Ágar Oxford Modificado (MOX) $\left(\right.$ Difco $\left.^{\mathrm{tm}}\right)$, suplementado com colistina e moxalactam) e incubados à $35^{\circ} \mathrm{C}$ em estufa bacteriológica (Quimis (®) por 24h,as colônias típicas foram submetidas à identificação por testes bioquímicos padrão tais como: coloração de Gram, teste de catalase e motilidade a $25^{\circ} \mathrm{C}$ e $37^{\circ} \mathrm{C}$ (PAGOTTO et al. 2001). Para a identificação e confirmação da espécie L. monocytogenes, foi utilizada a técnica de Reação de Polimerase em Cadeia (PCR) (MyCycler Bio-Rad), descrita por Kérouanton et al. (2010).

Para a realização do isolamento microbiológico de amostras ambientais foram coletadas por meio de swab individuais, friccionados em uma área de $10 \mathrm{~cm}^{2}$. Após a coleta das amostras, os swabs foram acondicionados, individualmente, em tubos contendo $10 \mathrm{~mL}$ de água peptonada à concentração de $0,1 \%$ e transportadas até o Laboratório de Microbiologia dos Alimentos (LAMAL) da Faculdade de Agronomia e Medicina Veterinária da Universidade de Brasília, em caixas isotérmicas e foram analisadas em até 24 horas pós-coleta, seguindo as normas descritas pela Instrução Normativa $\mathrm{n}^{\circ} 40$ de 2005, do Ministério da Agricultura, Pecuária e Abastecimento MAPA (Brasil, 2005).

\section{Sorotipificação}

As cepas de Listeria monocytogenes foram sorotipificadas pela técnica da reação em cadeia da polimerase (PCR), no Laboratório de Microbiologia dos Alimentos (LAMAL), da Faculdade de Agronomia e Medicina Veterinária, da Universidade de Brasília, conforme as recomendações descritas por Doumith et al. (2004). 


\section{Teste de resistência aos antimicrobianos}

Os testes de susceptibilidade antimicrobiana das cepas de Listeria monocytogenes foram realizados pelo método de difusão de disco, seguindo as orientações da Clinical \& Laboratory Standards Institute (CLSI, 2012) e para cada colônia isolada foi utilizada as seguintes bases farmacológicas: ácido nalidíxico (NAL: $30 \mu \mathrm{g}$ ), amoxicilina (AMX: 10 $\mathrm{g}$ ), ampicilina (AMP: 10 $\mu \mathrm{g}$ ), ciprofloxacino (CIP: $5 \mu \mathrm{g}$ ), cloranfenicol (C:30 $\mu \mathrm{g}$ ), eritromicina (E: $15 \mu \mathrm{g}$ ), gentamicina

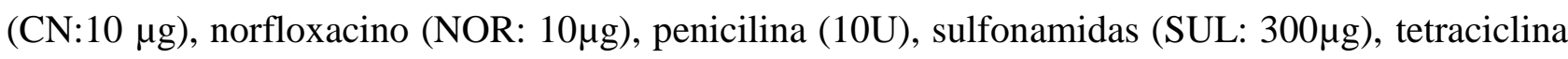
(TE: $30 \mu \mathrm{g}$ ), vancomicina (VA: $5 \mu \mathrm{g}$ ).As cepas isoladas foram cultivadas em caldo BHI(marca), e posteriormente transferidas para ágar de Mueller-Hinton (Oxoid CM 337),e incubadas em estufa bacteriológica (Quimis $®$ ) a $37^{\circ} \mathrm{C}$ durante $48 \mathrm{~h}$. Após esse período foram realizadas as leituras dos resultados, medindo-se o tamanho das zonas de inibição de crescimento bacteriano com um halômetro, sendo a cepa bacteriana classificada como resistente, intermediária e sensível, de acordo com o diâmetro da zona padrão estabelecida pelo CLSI (2012).

\section{Eletroforese de campo pulsante (PFGE)}

As 13 cepas de Listeria monocytogenes foram levadas ao Laboratório de Enterobactérias (LABENT) da Fundação Oswaldo Cruz - Rio de Janeiro, para serem submetidas à eletroforese em campo pulsante (PFGE). Todas as culturas obtidas foram submetidas à extração de DNA cromossomal de acordo com o protocolo recomendado pelo Center for Diseases Control and Prevention (PULSENET, 2009) para subtipagem de Listeria monocytogenes (Graves and Swaminathan, 2001) e a digestão enzimática foi realizada utilizando a enzima ApaI (Roche Diagnostics). Os produtos da clivagem foram separados em gel de agarose 1\% (Pulsed Field Agarose, BioRad) em tampão TBE 0,5X (0,9M Tris base, 0,9 M ácido bórico, 0,02 M EDTA, pH $8,0)$, por um período de 19 horas $(6 \mathrm{~V} / \mathrm{cm}-1)$, em equipamento de eletroforese de campo pulsado (CHEFDRIII). O tempo de pulso inicial foi de 4 segundos e o tempo final de 40 segundos. A cepa padrão de Salmonella Braenderup (ATCC BAA-664), clivada com a enzima XbaI (Roche Diagnostics), serviu como referência de tamanho dos fragmentos gerados. Após a corrida, o gel foi corado em solução de brometo de etídio $(10 \mathrm{mg} / \mathrm{mL})$ diluída $(1: 10.000)$ em água destilada. O 
equipamento Imagequant (Gelifesciences) foi utilizado para capturar as imagens sob luz Ultravioleta. O perfil de macro restrição foi analisado visualmente e cada posição de banda foi determinada por comparação com a cepa referência. Isolados com uma banda de diferença foram considerados como sendo de pulsotipos diferentes (FERRONATTO et al. 2012). 


\section{RESULTADOS E DISCUSSÃO}

\section{Isolamento microbiológico em amostras de cortes cárneos bovinos, swabs de carcaças bovinas e ambiente de abatedouros frigoríficos de bovinos localizados no Distrito Federal}

Das 125 amostras de cortes cárneos bovinos comercializados no Distrito Federal analisados foram detectados $11(8,9 \%)$ cepas de Listeria monocytogenes. Das 45 amostras de swabs obtidos de meias carcaças bovinas de abatedouros frigoríficos de bovinos localizados no Distrito Federal nenhuma cepa de Listeria monocytogenes foi encontrada, e das 43 amostras de swabs obtidas de ambiente de abatedouros frigoríficos de bovinos foram isoladas duas (2) cepas de Listeria monocytogenes, ambas oriundas de ralos de escoamentos.

Em relação às detecções de L. monocytogenes obtidas em cortes cárneos bovinos os resultados encontrados no presente estudo foram similares aos observados por Rocha et al. (2008) em que encontraram $4(11,4 \%)$ Listeria monocytogenes em 35 amostras de carne bovina homogeneizadas, comercializadas a granel no Distrito Federal. Os resultados deste estudo também se assemelham aos conduzidos por Mantilla et al. (2007), onde encontraram duas (6,7\%) amostras positivas para L. monocytogenes em 30 amostras de carnes moídas analisadas no município de Niterói, Rio de Janeiro. Novaes et al. (2014) também encontraram resultado similar aos deste estudo, de presença de uma (1) (4,55\%) cepa de Listeria monocytogenes, em 50 amostras de carpacio, no município de Niterói, Rio de Janeiro. Estão de concordância também os resultados relatados por Yucel et al. (2005) em Ankara, Turquia, em que esses autores encontraram uma (1) $(5.2 \%)$ amostras positivas para Listeria monocytogenes. Entretanto os resultados deste estudo divergiram aos dados obtidos em pesquisa realizada por Kasnowski (2004), em que os autores encontraram (30,1\%) de cepas de Listeria monocytogenes em 30 amostras de carnes bovinas no Rio de Janeiro, e Mena et al. (2004) em Portugal, 3 (17,7\%) em 17 amostras de carne. Várias são as possibilidades de contaminação por Listeria monocytogenes dos cortes cárneos bovinos, podendo ser no momento da desossa, no setor de cortes, na câmara fria, durante o transporte e até mesmo 
dentro dos supermercados. Caselani et al. (2013) relataram em seu estudo que o setor de cortes apresentou ser o ponto com maior contaminação em um matadouro frigorífico, com $10(18,9 \%)$ amostras positivas para Listeria spp., dentre os 53 swabs analisados da sala de corte e em segundo lugar a sala de desossa, com 18,4\% (21) de amostras positivas, em um total de 114 amostras de swabs ambientais da sala de desossa analisadas. Peccio et al. (2003) não isolaram nenhuma cepa de L. monocytogenes em câmara fria em abatedouros frigoríficos de carnes suína e bovina, no entanto foram encontradas em máquinas de picar carne e trituradores, em instalações de processamento de carnes suína, e em facas utilizadas em matadouro frigoríficos de bovinos. Gudbjornsdottir et al. (2003) em estudo conduzido nos Países Nórdicos, detectaram que as correias transportadoras de carcaças e os carrinhos de transporte eram os locais com maior contaminação de Listeria monocytogenes. Os resultados obtidos nesta etapa deste estudo demonstram que há contaminações por L. monocytogenes em cortes cárneos bovinos, evidenciando a necessidade de realizações de maiores pesquisas na cadeia de processamento deste produto.

Em relação às detecções de L. monocytogenes obtidas de swabs de carcaças bovinas, Matos et al. (2013) também não encontraram nenhuma cepa de Listeria monocytogenes em 100 swabs de carcaças analisadas, em um abatedouro frigorífico de carne bovina localizado no interior do Estado de São Paulo. Silveira, (2010) observaram que em 110 swabs de carcaças bovinas analisadas na região serrana do Rio Grande do Sul, nenhuma carcaça bovina era positiva para Listeria monocytogenes, no entanto em swabs realizados em etapa anterior a esfola, ou seja, na superfície da pele, 4 superfícies de peles de distintas carcaças $(3,63 \%)$ foram positivas para Listeria monocytogenes. Os resultados obtidos por Picchi et al. (1999) foram diferentes aos encontrados neste trabalho, pois estes autores detectaram L. monocytogenes em (5) $20 \%$ de quartos dianteiros bovinos, originários de matadouros-frigoríficos mantidos sob Inspeção Federal permanente. A ausência de Listeria monocytogenes observada neste estudo não permite afirmar que essa bactéria não ocorra nas carcaças de bovinos, tendo em vista pesquisas que evidenciam a presença deste microrganismo na superfície da pele de bovinos. Os resultados negativos provavelmente se devem ao pequeno número de carcaças amostradas. Um maior número de carcaças devem ser analisadas, bem como um maior número de indústrias frigoríficas.

Em relação aos resultados das detecções de swabs ambientais de abatedouro frigorifico, Lambertz et al. (2013) encontraram uma (3,8\%) cepa de Listeria monocytogenes em 26 amostras de 
ambientes em plantas de processamento de carne bovina, e Silveira (2010) identificou uma (0,5\%) cepa de Listeria monocytogenes entre as 200 amostras analisadas na região serrana do Rio Grande do Sul. Entretanto estudos realizados por Caselani et al. (2013), em um matadouro frigorífico de bovinos localizado em Barretos-SP, verificaram que das 411 amostras de swabs ambientais, 21 $(5,1 \%)$ amostras de swabs foram positivas para L. monocytogenes e dentre essas, $8(5,8 \%)$ cepas de L. monocytogenes foram oriundas do ralo. Peccio et al. (2003) ao analisarem amostras de superfícies de ambiente e equipamentos em abatedouros frigoríficos de Suíno e bovino no Nordeste da Itália, detectaram L. monocytogenes em 6,5\% das amostras, sendo todas as cepas isoladas das facas. Apesar do reduzido número de amostras analisadas neste estudo, a presença desta bactéria nos ralos de escoamento em ambiente de abatedouros frigoríficos de bovino analisados no presente estudo sugerem possíveis falhas na realização adequada dos procedimentos de limpeza e sanitização. Maiores estudos devem ser conduzidos para se verificarem os principais focos de contaminação em plantas de abatedouros frigoríficos de bovinos.

\section{Sorotipificação pela técnica da reação em cadeia da polimerase em cepas de Listeria monocytogenes isoladas de cortes cárneos bovinos e ambientes de abatedouros frigoríficos}

Os sorotipos encontrados, dentre as treze (13) cepas de Listeria monocytogenes isoladas neste estudo, seis (6) cepas foram do sorotipo $4 \mathrm{~b}$ isoladas das amostras de cortes cárneos bovinos, cinco (5) cepas do sorotipo $1 / 2 \mathrm{c}$ isoladas das amostras de carnes bovinos e duas (2) cepas do sorotipo 1/2a isoladas dos ralos dos ambientes da indústria frigorífica. Os resultados com os sorotipos e a origem das cepas isoladas neste estudo encontram-se na Tabela 1.

Os resultados observados neste estudo, em que o sorotipo $4 \mathrm{~b}$ foi o mais encontrado, seguido pelo segundo sorotipo 1/2c e 1/2a, foram similares aos observados por Hofer et al. (2006), em que encontraram em seus estudos uma maior porcentagem do sorotipo 4b com (60,3\%) em 255 cepas de Listeria monocytogenes isoladas de materiais clínicos durante os anos de 1969 a 2000, em diferentes regiões pelo método de antissoros somáticos e flagelares policlonais polivalentes e monovalentes produzidos pelo Laboratório de Zoonoses Bacterianas, Instituto Oswaldo Cruz/FIOCRUZ, RJ. Entretanto em um estudo feito por Camargo et al. (2013) em instalações de 
processamento de carne, em Viçosa, MG, demonstrou por PCR multiplex que o sorotipo mais encontrado foi o 1/2c e Kramarenko et al. (2013) encontraram em diferentes tipos de alimentos na Estônia, 73,6\% do sorotipo 1/2a, seguido do sorotipo 4 b com 7,7\% e 7,4\% do sorotipo 1/2b e 1/2c. No trabalho realizado por Shi et al. (2015) também encontraram resultados diferentes com 37 cepas $(46,25 \%)$ de Listeria monocytogenes pertencentes ao sorotipo 1/2a e 3a, sendo 21 isolados (26,25\%) pertencentes ao sorotipo 4b, 4d e 4e, 17 isolados pertenciam ao sorotipo 1/2b, $3 \mathrm{~b}$ e 5 isolados $(6,25 \%)$ pertenciam ao sorotipo $1 / 2 \mathrm{c}$ e $3 \mathrm{c}$ em amostras de alimentos "ready-to-eat" em 24 diferentes cidades na China. A identificação de cepas de L. monocytogenes pertencentes ao sorogrupo $4 \mathrm{~b}$ no presente estudo é relevante devido ao seu potencial patogênico e associação com casos e surtos de listeriose segundo os autores Swaminathan \& Gerner-Smidt, (2007).

Tabela 1- Resultado da sorotipificação das 13 cepas de Listeria monocytogenes isoladas de cortes cárneos comercializados no Distrito Federal e swabs de ambiente oriundas de abatedouro frigorífico no Distrito Federal.

\begin{tabular}{ccc}
\hline $\begin{array}{r}\text { Origem das cepas } d \\
\text { L. monocytogenes }\end{array}$ & Sorotipos & $\begin{array}{c}\text { Cepas de } L . \\
\text { monocytogenes } \\
N=13\end{array}$ \\
\hline Cortes cárneos & $4 b$ & 6 \\
\cline { 2 - 3 } & $1 / 2 c$ & 5 \\
\hline Ralo & $1 / 2 a$ & 2 \\
\hline
\end{tabular}

A utilização da PCR para sorotipificação tem sido uma técnica bastante empregada para a caracterização das cepas de Listeria monocytogenes (Doumith et al. 2004a, 2005). Na Figura 1 encontram-se alguns dos resultados das reações das PCRs para identificação das cepas isoladas de cortes cárneos bovinos, e das cepas oriundas dos ralos dos ambientes de abatedouros frigoríficos no Distrito Federal.

Entre as cepas $4 \mathrm{~b}$ isoladas, 3 cepas tiveram uma dupla amplificação do fragmento de DNA 1 mo0737 ( 691 pb), denominado por Leclercq et al., (2011) de 'profile IVb variant 1' (IVb-v1) (Figura 1). No mesmo estudo feito por Leclercq et al. (2011) eles aplicaram o método de 
sorotipagem por PCR para cerca de 9000 cepas de Listeria monocytogenes, destes, 22 cepas oriundas da Argélia, Brasil, França e Suíça exibiram também esse novo perfil atípico de sorogrupo IVb e concluíram que essas cepas com perfil de sorogrupo IVb-v1 não parecem ter uma origem clonal recente, pois não é uma estirpe emergente, tal como foi observado no estudo realizado por Leclercq et al. (2011) em uma cepa isolada em 1959 na Suíça, a partir da coleção de culturas do Centro de Referência Nacional e da OMS-CC para Listeria (Coleções de Listeria do Instituto Pasteur, CLIP).

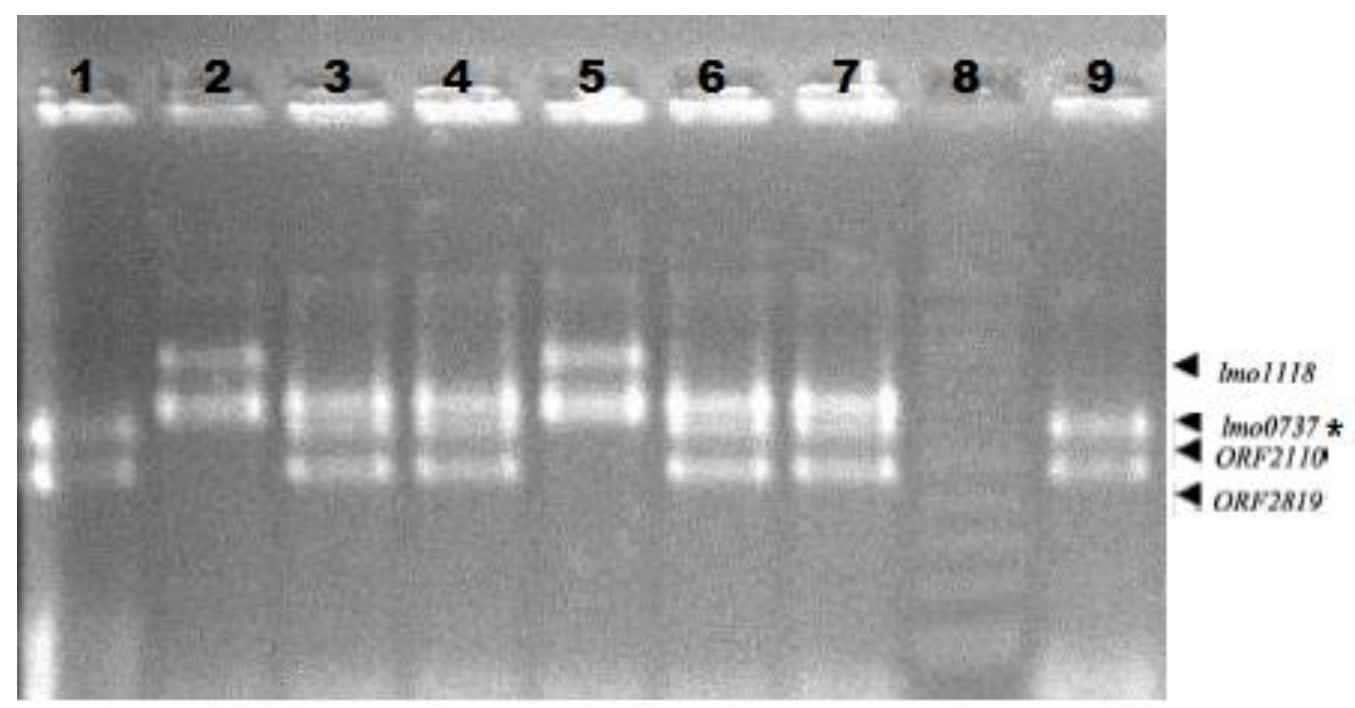

Figura 1 - Resultado da PCR para identificação dos sorotipos de Listeria monocytogenes isoladas de cortes cárneos e swabs de abatedouro frigorifico no Distrito Federal. 1) cepa de referência para o sorotipo $4 \mathrm{~b}$ oriunda da FIOCRUZ-RJ $(471 \mathrm{pb}$ e $597 \mathrm{pb})$; 2) cepa de referência para o sorotipo 1/2c oriunda da FIOCRUZ-RJ (691pb e 906pb); 3,4,6 e 7) fragmentos da dupla amplificação do fragmento de DNA lmo0737 (691 pb), sorogrupo IVb-V1 isoladas de cortes cárneos (*); 5) sorotipo 1/2c (691pb e 906pb); 8) 100 bp DNA ladder; 9) sorotipo 4b ( 471pb e $597 \mathrm{pb}$ ). Visualização em transiluminador Imagequant (Gelifesciences) em gel de agarose a $2 \%$ com concentração de $5 \mathrm{mg} / \mathrm{ml}$ de brometo de etídio.

\section{Teste de susceptibilidade antimicrobiana}


Dentre as 11 cepas de L. monocytogenes encontradas em cortes cárneos bovino, uma $(9,1 \%)$ cepa apresentou resistência a eritromicina, outra $(9,1 \%)$ cepa a gentamicina e outra a ciprofloxacina $(9,1 \%)$ e todas as cepas $(100 \%)$ apresentaram resistência ao Ác. nalidíxico. Das duas (2) cepas oriundas de ralos de abatedouro frigorífico, todas (100\%) apresentaram resistência ao Ác. nalidíxico e a sulfonamidas, conforme podem ser observados na Tabela 2.

Tabela 2 - Teste de resistência antimicrobiana realizado em 13 cepas de Listeria monocytogenes isoladas de cortes cárneos bovinos comercializados no Distrito Federal e swabs de ambiente oriundas de abatedouro frigorífico

\begin{tabular}{|c|c|c|c|c|c|c|}
\hline \multirow[t]{2}{*}{$\begin{array}{l}\text { Agente } \\
\text { antimicrobiano }\end{array}$} & \multicolumn{3}{|c|}{$\begin{array}{l}\text { Cepas isoladas de cortes cárneos } \\
\text { bovinos }(\mathrm{n}=11)\end{array}$} & \multicolumn{3}{|c|}{$\begin{array}{c}\text { Cepas isoladas de swabs de ralc } \\
\text { de abatedouro frigorífico de } \\
\text { bovinos }(\mathrm{n}=2)\end{array}$} \\
\hline & $\mathrm{S}$ & $\mathrm{I}$ & $\mathrm{R}$ & $S$ & I & $\mathrm{R}$ \\
\hline Amoxicilina & $11(100 \%)$ & 0 & 0 & $2(100 \%)$ & 0 & 0 \\
\hline Cefalosporina & $11(100 \%)$ & 0 & 0 & $2(100 \%)$ & 0 & 0 \\
\hline Ciprofloxacino & $7(63,6 \%)$ & $3(27,3 \%)$ & $1(9,1 \%)$ & $1(50 \%)$ & $1(50 \%)$ & 0 \\
\hline Cloranfenicol & $11(100 \%)$ & 0 & 0 & $2(100 \%)$ & 0 & 0 \\
\hline Eritromicina & $10(90,9 \%)$ & 0 & $1(9,1 \%)$ & $2(100 \%)$ & 0 & 0 \\
\hline Gentamicina & $10(90,9 \%)$ & 0 & $1(9,1 \%)$ & $2(100 \%)$ & 0 & 0 \\
\hline Ác. Nalidíxico & 0 & 0 & $11(100 \%)$ & 0 & 0 & $2(100 \%)$ \\
\hline Norfloxacina & $9(81,8 \%)$ & $2(18,2 \%)$ & 0 & $2(100 \%)$ & 0 & 0 \\
\hline Penicilina & $11(100 \%)$ & 0 & 0 & $2(100 \%)$ & 0 & 0 \\
\hline Sulfonamidas & $3(27,3 \%)$ & 0 & $8(72,7 \%)$ & 0 & 0 & $2(100 \%)$ \\
\hline Tetraciclina & $11(100 \%)$ & 0 & 0 & $2(100 \%)$ & 0 & 0 \\
\hline Vancomicina & $11(100 \%)$ & 0 & 0 & $2(100 \%)$ & 0 & 0 \\
\hline
\end{tabular}

Os perfis antimicrobianos para as cepas de Listeria monocytogenes isoladas mostraram uma baixa porcentagem de cepas resistentes a uma variedade de antibióticos incluindo algumas bases utilizadas na terapia com humanos para tratamento de casos de listeriose, tais como a Penicilina e 
Gentamicina (Tabela 2). Enquanto a maioria dos isolados foi sensível a todos os antimicrobianos analisados (Tabela 2), apenas uma cepa demonstrou resistência à gentamicina que é a opção de tratamento recomendado para casos de listeriose durante a gravidez (janakiraman, 2008). Em estudos realizados por Wieczorek et al. (2012) em Listeria monocytogenes isoladas de couros e carcaças bovinas, os autores encontraram também uma baixa porcentagem de cepas resistentes à Gentamicina com apenas 1 (1,9\%). Khen et al. (2015) também encontraram uma baixa porcentagem de cepas resistentes a esse antibiótico, de 73 cepas analisadas em Dublin, na Irlanda apenas 4 (5\%) apresentaram resistência a essa droga.

Apesar da baixa porcentagem de resistência antimicrobiana observada neste estudo, foi verificado que ela está presente nos microrganismos isolados neste estudo. Não se pode afirmar que ela se encontra em baixa prevalência devido ao baixo número de amostras analisadas, entretanto pode-se afirmar que há ocorrência. A presença de cepas de L. monocytogenes resistentes aos antimicrobianos utilizados no tratamento da listeriose humana pode levar a um problema para saúde humana, pois esse tipo de bactéria afeta principalmente imunossuprimidos, idosos, crianças e mulheres grávidas (MANTILLA et al. 2007). São necessários mais estudos para uma melhor compreensão da presença desta resistência em cepas de Listeria monocytogenes bem como identificar a real fonte de origem da resistência antimicrobiana.

\section{Análises de PFGE}

Baseado nas análises de macrorestrição por PFGE obtidos com a enzima de restrição Apal, os isolados de Listeria monocytogenes resultaram em 8 pulsotipos, e mostraram uma divisão em três grupos clonais, segundo o BioNumerics software version 4.0 (Applied Maths, Belgium), que faz a correlação entre os perfis genéticos obtidos com a enzima de restrição Apal (Figura 2) com um valor de corte mínimo de $80 \%$ de similaridade como proposto por Franciosa et al. (2005). Os isolados foram obtidos de cortes cárneos bovinos comercializados no Distrito Federal e em ralos de ambiente de abatedouro frigorífico. O grupo A coincidentemente foi composto por todas as cepas pertencentes ao sorotipo $1 / 2 \mathrm{c}$, e apresentou dois perfis genéticos distintos com $87 \%$ de similaridade

entre si. O grupo B apresentou 2 diferentes pulsotipos com 95\% de similaridade entre si e coincidentemente identificados como pertencentes ao sorotipo 1/2a. Os isolados do grupo (C) 
apresentaram quatro perfis genéticos distintos, todos eles coincidentemente pertencentes ao sorotipo 4b com similaridade entre si de $80 \%$. Isolados do grupo A e C de um mesmo pulsotipo foram obtidos em diferentes amostras de cortes cárneos bovinos de diferentes regiões do Distrito Federal e isolados do grupo B foram obtidos de diferentes ralos em um mesmo abatedouro frigorifico no Distrito Federal em diferentes épocas de isolamento (Figura 2).

Estudos feito por Gianfranceschi et al. (2009) demonstraram que havia uma correlação quase completa entre os pulsotipos e sorotipos por eles analisados, uma vez que 95,0\% dos seus isolados que obtiveram padrões de PFGE idênticos pertenciam ao mesmo sorotipo, e apenas 5\% de todos os isolados analisados com os mesmos pulsotipos pertenciam a diferentes sorotipos mas pertencentes à mesma linhagem genética. Assemelhando-se ao encontrado no presente trabalho em que ocorreram $100 \%$ de correlação entre os pulsotipos e sorotipos analisados. Perfis moleculares determinados por PFGE semelhantes indicam uma possível relação clonal entre os isolados e isso acontece somente quando ocorre um único evento genético como uma mutação, uma inserção ou deleção, que altere o padrão das bandas (MAGALHÃES et al. 2005; CRUZ et al. 2008).

Camargo (2013) identificou em seu trabalho diferentes rotas de contaminação no ambiente de processamento de carne bovina em que isolados com perfis genéticos idênticos foram encontrados em utensílios limpos e sujos, de diferentes cortes finais, e entre utensílios e cortes finais e concluiu que esses resultados analisados em seu trabalho corroborariam com a importância da contaminação cruzada na transmissão desta bactéria dentro de uma planta de processamento da indústria frigorífica. Galvão et al (2012) também identificaram potenciais vias de contaminação e permanência de cepas nos estabelecimentos por ele avaliado, em que um isolado observado em um estabelecimento de processamento foi obtido a partir do produto final (carne moída) e apresentou uma similaridade de $82 \%$ com outros seis outros isolados, todos obtidos no mesmo estabelecimento em datas anteriores realizados durante um período de 5 meses.

No presente estudo cepas foram observadas a partir de diferentes cortes cárneos bovinos comercializados em diferentes regiões do Distrito Federal, bem como em um abatedouro frigorifico em diferentes épocas de isolamento. Esse resultado pode sugerir uma ampla disseminação destes genótipos no Distrito Federal e uma possível persistência da cepa no ambiente causado por uma falha dos procedimentos de limpeza e sanitização adotados no próprio abatedouro frigorífico. Porém devido ao pequeno número de amostras analisadas maiores estudos precisam ser realizados 
para que possa se confirmar a correlação entre as origens dessas cepas e sua possível permanência nos abatedouros frigoríficos. 


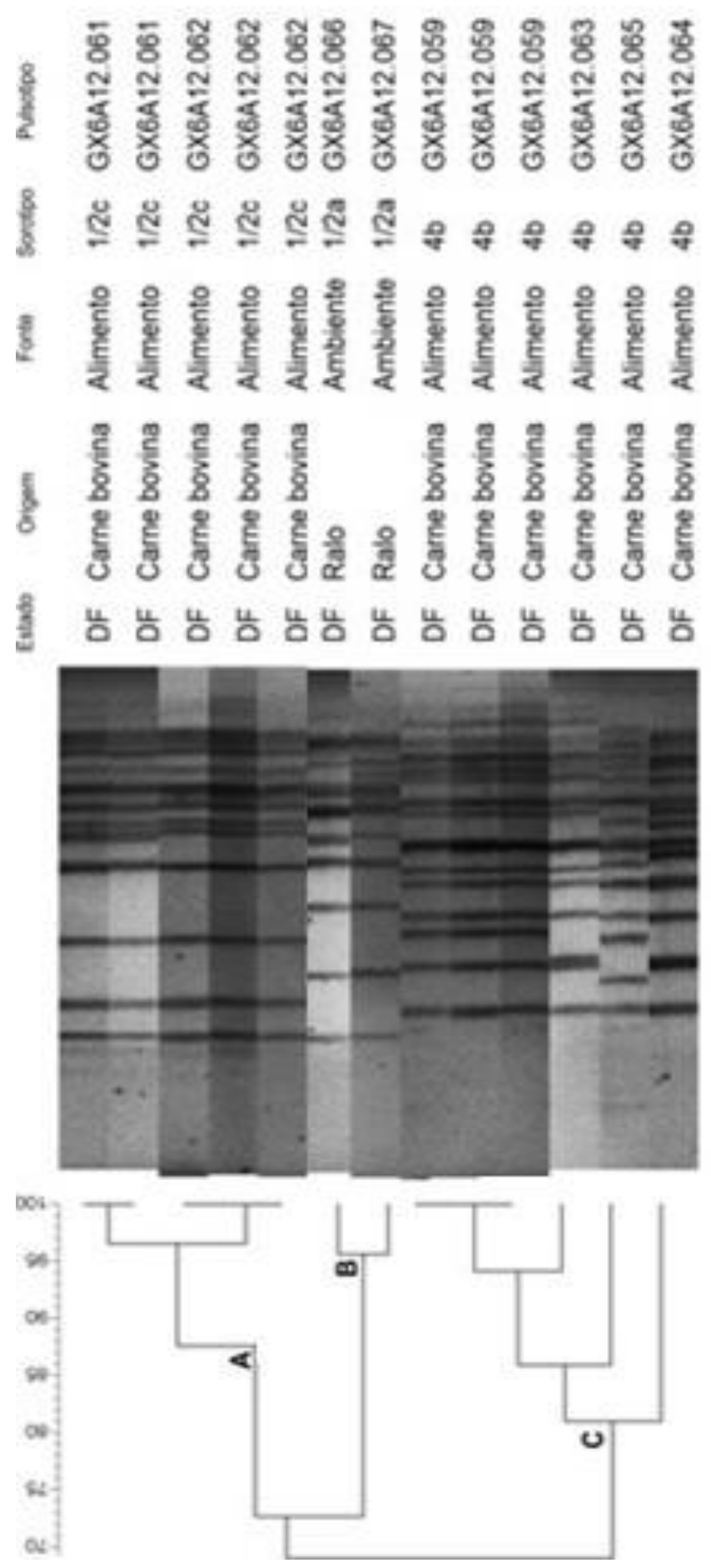

Figura 2- Perfis PFGE obtidos com a enzima de restrição ApaI (Roche Diagnostics) para as 13 cepas de L. monocytogenes isoladas em cortes cárneos bovino e swabs de ralo em abatedouro frigoríficos de bovinos no Distrito Federal. 


\section{CONCLUSÃO}

Os resultados encontrados neste trabalho permitem concluir que há a presença de $L$. monocytogenes em cortes cárneos bovinos e em ambientes de abatedouro Frigorifico no Distrito Federal. Os principais sorotipos encontrados foram o 4b, 1/2a e 1/2c. Dentre as cepas de $L$. monocytogenes encontradas em cortes cárneos bovinos, ocorreram resistência à eritromicina, gentamicina e ciprofloxacina. Todas as cepas apresentaram resistência ao Ácido nalidíxico. Das cepas oriundas de ralos de abatedouro frigorífico, todas apresentaram resistência ao Ác. Nalidíxico e a sulfonamidas. A análise por eletroforese de campo pulsante (PFGE) resultou em 8 diferentes pulsotipos, e mostraram uma divisão em três grupos que coincidentemente separou os 3 sorotipos, sugerindo uma ampla disseminação destes genótipos no Distrito Federal. Os resultados ainda sinalizam para que se realizem maiores estudos para verificar a abrangência deste microrganismo nos cortes cárneos bovinos e abatedouros frigoríficos tendo em vista a importância desta bactéria para a saúde pública. 


\section{REFERÊNCIA BIBLIOGRÁFICA}

ASSOCIAÇÃO BRASILEIRA DE NORMAS TÉCNICAS - ABNT. Preparo da amostra para exame microbiológico. Rio de Janeiro: ABNT, 1988.

BARBOSA, A.V. CERQUEIRA, A.M.F., RUSAK, L.A., REIS, C.M.F., LEAL, N.C., HOFER, E., VALLIM, D.C. Characterization of epidemic clones of Listeria monocytogenes serotype 4b isolated from humans and meat products in Brazil. J Infect Dev Ctries 2015; 9(9):962-969. 2015.

BORUCKI M.K, CALL D.R. Listeria monocytogenes serotype identification by PCR. J Clin Microbiol 41:5537-5540. 2003

BORUCKI, M. K.; KIM, S. H.; CALL, D. R.; SMOLE, S. C.; PAGOTTO, F. Selective Discrimination of Listeria monocytogenes Epidemic Strains by a MixedGenome DNA Microarray Compared to Discrimination by Pulsed-Field Gel Electrophoresis, Ribotyping, and Multilocus Sequence Typing. J of Clinical Micro, v. 42, n. 11, p. 5270-5276, 2004.

BRASIL. Ministério da Agricultura, Pecuária e Abastecimento. Instrução Normativa no 40 de 12 de dezembro de 2005. Aprovar os Métodos Analíticos, Isolamento e Identificação da Salmonella na carne bovina, avicultura e produtos derivados de ovos - MLG - 4.03, Metodologia Alternativa de Salmonella A-Bax -MLG 4C .01, Isolamento e Identificação de Listeria monocytogenes em carne vermelha, carne de ave, ovos e amostras ambientais, MLG 8.04 Metodologia Alternativa de Listeria A-BAX MLG-8 A .01, Escherichia coli, MPN AOAC 966.24, Método Petrifilm AOAC 998.08, que passam a constituir Padrões Oficiais para Análise de Microbiologia de Produtos de Origem Animal. DOU, 16/12/2005, seção 1, p.70, 2005.

CAMARGO, A. C. Caracterização fenotípica e molecular de isolados de Listeria monocytogenes obtidos em uma planta de processamento de carne bovina, em Viçosa, MG. (Dissertação de mestrado para obtenção do titulo Magister Scientiae) - Universidade Federal Viçosa, Minas Gerais, 2013. 
CARTWRIGHT, E.J., JACKSON, K.A., JOHNSON, S.D. GRAVES, L.M., SILK, B.J., MAHON, B.E. Listeriosis outbreaks and associated food vehicles, United States, 1998-2008. Emerging and infectious Diseases, 19, 1-9, 2013.

CASELANI, K.; PRATA, L. F.; BIZARI, P. A.; PEREIRA, G. T.; MARCHI, P. G. F.; PICINATO, M. A. C. Ocorrência de Listeria spp. E de Listeria monocytogenes, em um matadourofrigorífico de bovinos do estado de São Paulo. Biosci. J., Uberlândia, v. 29, n. 4, p. 956-961, July/Aug. 2013

CHEN Y, KNABEL S.J. Multiplex PCR for simultaneous detection of bacteria of the genus Listeria, Listeria monocytogenes, and major serotypes and epidemic clones of $L$. monocytogenes. Appl. Environ. Microbiol.73: 6299 - 6304. 2007

CLINICAL AND LABORATORY STANDARDS INSTITUTE (CLSI). Methods for Antimicrobial Dilutions and Disk Susceptibility Testing of Infrequently Isolated or Fastidious Bacteria; AprovedGuidiline (M45-A), v.26, n.19, 2009.

CRUZ, C. D.; MARTINEZ, M. B.; DESTRO, M. T. Listeria monocytogenes: um agente infeccioso ainda pouco conhecido no Brasil. Alim. Nutr. ISSN 0103-4235 , v.19, n.2, p. 195-206, abr./jun. 2008

DOUCET-POPULAIRE, F., TRIEU-CUOT, P., DOSBAA, I., ANDREMONT, A., COURVALIN, P. Inducible transfer of conjugative transposon Tn1545 from Enterococcus faecalis to Listeria monocytogenes in the digestive tract of gnotobiotic mice. Antimicrobial Agents and Chemotherapy $35,185 \pm 187,1991$.

DOUMITH, M.; BUCHRIESER, C.; GLASER, P.; JACQUET, C.; MARTIN, P. Differentiation of the major Listeria monocytogenes serovars by multiplex PCR. Journal of Clinical Microbiology, v.42, n.8, p.3819-3822, 2004.

FERRONATTO, A. I., PELLEGRINI, D.C.P., GUERRA, P., CARDOSO, M.R.I. Distribuição de grupos clonais de Listeria monocytogenes em carcaças e no ambiente de matadouros frigoríficos de suínos. Archives of Veterinary Science. v.17, n.3, p.42-49, 2012 
FRANCIOSA, G.; MAUGLIANI, A.; FLORIDI, F.; AURELI, P. Molecular and experimental virulence of Listeria monocytogenes strains isolated from cases with invasive listeriosis and febrile gastroenteritis. FEMS Immunology and Medical Microbiology, v.43, n.3 p.431-439, 2005.

GAlleGOS, J.M., VANEGAS, M.C., AlBARRACÍN, Y., MÁTtAR, S., POUTOU, R.A., CARRASCAL, A.K Frequency of isolation of Listeria spp., in different retail foods in Colombia. Animal Production Research Advances 4: 9-18, 2008.

GAlVÃO, N.N., CHIARINI E, DESTRO M.T., AGUIAR F.M, NERO L. A.. PFGE characterisation and adhesion ability of Listeria monocytogenes isolates obtained from bovine carcasses and beef processing facilities. Meat Science, v.92, n.4, p.635-643. 2012

GERNER-SMIDT, P., HISE, K. KINCAID, J., HUNTER, S., ROLANDO, S., HYYTIA-TREES, E., RIBOT, E.M. SWAMINATHAN, B. PulseNet USA: a five-year update, Foodborne Pathog. Dis. 3 9-19. 2006.

GIANFRANCESCHI, M.V., D'OtTAVIO, M.C., GATTUSO, A., BELlA, A., AURELI, P. Distribution of serotypes and pulsotypes of Listeria monocytogenes from human, food and environmental isolates (Italy 2002-2005). Food Microbiology 26, 520-526. 2009.

GUDBJÖRNSDÓTTIR, B., SUIHKO M.L., GUSTAVSSON, P., THORKELSSON, G., SALO, S., SJÖBERG, A. M., NICLASEN, O., BREDHOLT, S. The incidence of Listeria monocytogenes in meat, poultry and seafood plants in the Nordic countries. Food Microbiology 21. 217-225. 2004.

GRAVES, L.M.; SWAMINATHAN, B. PulseNet standardized protocol for subtyping Listeria monocytogenes by macrorestriction and pulsed-field gel electrophoresis. International Journal Food Microbiology, v.65, n.1-2, p.55-62, 2001.

HOFER, E., REIS, C. M., HOFER, C. B. Serovars of Listeria monocytogenes and related species isolated from human clinical specimens. Rev. Soc. Bras. Med. Trop., v.39, n.1, p.32-37, Jan.Feb. 2006 
JARDIM, F. B.B., SILVA, E. N., OKURA, M. H., RAMOS, M. A. Influência dos sistemas de pastagem e confinamento na contaminação microbiana de carcaças bovinas. Ciênc. Tecnol. Aliment., Campinas , v. 26, n. 2, p. 277-282, junho 2006 . Disponível em: $<$ http://www.scielo.br/scielo.php?script=sci_arttext\&pid=S0101-

20612006000200008\&lng=en\&nrm=iso>. Acesso em 10 Dec. 2015

JANAKIRAMAN, V. Listeriosis in pregnancy, diagnosis, treatment and prevention. Rev. Obstet. Gynecol. 1, 179-185. 2008.

KASNOWSKI, M. C. Listeria spp., Escherichia coli: isolamento, identificação, estudo sorológico e antimicrobiano em corte de carne bovina (alcatra) inteira e moída. 110 f. Dissertação (Mestrado em Higiene Veterinária e Processamento Tecnológico de Produtos de Origem Animal) - Universidade Federal Fluminense, Niterói. 2004.

KEROUANTON, A., MARAult, M., PETIT, L., GROUT, J., DAO, T.T., BRISABOIS A. Evaluation of a multiplex PCR assay as an alternative method for Listeria monocytogenes serotyping J. Microbiol. Methods, 80 (2), pp. 134-137, 2010a

KEROUANTON, A.; ROCHE, S.M.; MARAULT, M.; VELGE, P.; POURCHER, A.M.; BRISABOIS, A.; FEDERIGHI, M.; GARREC, N. Characterization of isolates of Listeria monocytogenes from sludge using pulsed-field gel electrophoresis and virulence assays. Journal of Applied Microbiology, v.108, n.4, p.1380-1388, 2010.

KHEN, B.K., LYNCH, O. A., CARROLL, J., MCDOWELL, D. A., DUFFY, G. Occurrence, Antibiotic Resistance and Molecular Characterization of Listeria monocytogenes in the Beef Chain in the Republic of Ireland. Zoonoses and Public Health, 62, 11-17. 2015.

KRAMARENKO, T., ROASTO, M., MEREMÄE, K., KUNINGAS, M., PÕLTSAMA, P., ELIAS, T. Listeria monocytogenes prevalence and serotype diversity in various foods. FoodControl 30, 24-29. 2013.

LAMBERTZ S. T., IVARSSON S., LOPEZ-VALLADARES G., SIDSTEDT M., LINDQVIST R. (2013). Subtyping of Listeria monocytogenes isolates recovered from retail ready-to-eat foods, processing plants and listeriosis patients in Sweden 2010. Int. J. Food Microbiol. 166, 186-192. 10.1016/j.ijfoodmicro.2013.06.008 
LECLERCQ, A.; CHENAL-FRANCISQUE, V.; DIEYE, H.; CANTINELlI, T.; BRISSE, S.; LECUIT, M.DRALI R,. Characterization of the novel Listeria monocytogenes PCR serogrouping profile IVb-v1. Int J Food Microbiol 147: 74-77. 2011.

LECUIT, M. Human listeriosis and animal models. Microbes Infect 9:1216-1225, 2007.

MARTIN, P., JACQUET, C., GOULET, V., VAILLANT, V., DE VALK, H. \& Participants in the PulseNet Europe Feasibility Study Pulsed-field gel electrophoresis of Listeria monocytogenes strains: the PulseNet Europe Feasibility Study. Food borne Pathog Dis 3, 303-308, 2006.

MAGALHÃES, V. D.; FERREIRA, J. C.; BARELLI, C.;DARINI, A. L. C. Eletroforese em campo pulsante em bacteriologia - uma revisão técnica. Ver Inst Adolfo Lutz, 64(2):155-161,2005

MANTILlA, S. P. S.; FRANCO, R. M.; OLIVEIRA, L. A. T.; SANTOS, E. B.; GOUVÊA, R. ocorrência de listeria spp. em amostras de carne bovina moída comercializadas no município de Niterói, RJ, Brasil.Ciênc. agrotec., Lavras, v. 31, n. 4, p. 1225-1230, jul./ago., 2007.

MATOS, A.V.R.; NUNES, L.B.S.; VIANNA, C.; SPINA, T.L.B.; ZUIM, C.V.; POSSEBON, F.S.; XAVIER, D.M.; FERRAZ, M.C.; PINTO, J.P.A.N. Listeria monocytogenes, E. coli O157, Salmonella spp. e microrganismos indicadores em carcaças bovinas para exportação. Arq. Bras. Med. Vet. Zootec. vol.65 no.4 Belo Horizonte Aug. 2013

MENA, C. ALMEIDA, G.; CARNEIRO, L.; TEIXEIRA, P.; HOGG, T.; GIBBS, P. A. Incidence of Listeria monocytogenes in different food products commercialized in Portugal. Food Microbiology, Amsterdam, v. 21, p. 213-216, 2004.

MORENO, L. Z.; PAIXÃO, R.; GOBBI, D. D. S.; RAIMUNDO, D. C.; FERREIRA, T. P.; MORENO, A. M.; HOFER, E.; M. F.; REIS, C. M. F.; MATTÉ, G. R.; MATTÉ, M. H. Characterization of antibiotic resistance in Listeria spp. isolated from slaughterhouse environments, pork and human infections. J Infect Dev Ctries; 8(4):416-423. 2014. 
NOVAES, S. F.; ALVES, V. O.; LANZARIN, M.; RITTER, D. O.; FRANCO, R. M. Listeria spp. Em carpacio de carne bovina e perfil de resistência aos agentes antimicrobianos. Arq. Inst. Biol., São Paulo, v.81, n.4, p. 309-314, 2014

PAIllard, D., DUbOIS, V., DURAN, R., NATHIER, F., GUitTET, C., CAUMETTE, P., QUENTIN, C. Rapid identification of Listeria species by using restriction fragment length polymorphism of PCR-amplified 23S rRNA gene fragments. Applied and environmental microbiology, nov., p. 6386-6392, 2003.

PECCIO, A.; AUTIO, T.; KORKEALA, H.; ROSMINI, R.; TREVISANI, M. Listeria monocytogenes occurrence and characterization in meat-producing plants. Letters in Applied Microbiology, Oxford, v. 37, p. 234-238, 2003.

PICCHI, V., RAMOS SILVA, E. O. T., SOUZA, S. L. P., BALIAN, S. C. Isolamento e identificação de Listeria spp. em quartos dianteiros de bovinos desossados. Higiene Alimentar, v.13, n.63, p.38-42, 1999.

PULSENET. [2009]. The National Molecular Subtyping Network for Foodborne Disease Surveillance. Standardized Laboratory Protocol for Molecular Subtyping of Listeria monocytogenes by Pulsed Field Gel Electrophoresis (PFGE).Disponívelem:<http://www.cdc.gov/pulsenet>Acesso em: 05/09/2015.

ROCHA, R.A. Identificação microbiológica e diferenciação de espécies de Listeria spp. Por análise de restrição de fragmentos de PCR (RFLP-PCR) em amostras de carnes e derivados comercializados no distrito federal. Dissertação (Mestrado em saúde Animal) - Universidade de Brasília, Brasília, 2008.

SEELIGER, H. P. R., HÖHNE. K. Serotyping of Listeria monocytogenes and related species.MethodsMicrobiol. 13:31-49, 1979.

SILVEIRA, J. G. Investigação de listeriasp. E microrganismos mesófilos totais em carcaças bovinas e em ambiente industrial de abatedouro frigorífico. Porto Alegre (RS), Brasil Dezembro, 2010 
SCARCELLI, E., PIATTI, R.M. Patógenos Emergentes Relacionados à Contaminação de Alimentos de Origem Animal. InstitutoBiológico.v.64, n.2, p.123-127, 2002.

SHI, W.; QINGPING, W.; JUMEI, Z; MOUTONG, C. ; ZEA, Y. Prevalence, antibiotic resistance and genetic diversity of Listeria monocytogenes isolated from retail ready-to-eat

TROXLER R, VON GRAEVENITZ A, FUNKE G, WIEDEMANN A, STOCK I Natural antibiotic susceptibility of Listeria species: L. grayi, L. innocua, L. ivanovii, L. monocytogenes, L. seeligeri and L. welshimeri strains. ClinMicrobiol Infect 6: 525-535. (2000).

VANEGAS, M.C., VASQUEZ, E., MARTINEZ, A.J., RUEDA, A.M. Detection of Listeria monocytogenes in raw whole milk for human consumption in Colombia by real-time PCR. Food Control20: 430-432, 2009.

YUCEL, N.; CITAK, S.; ONDER, M. Prevalence and antibiotic resistance of Listeria species in meat products in Ankara, Turkey.Food Microbiology 22 241-2452005.

WIECZOREK, K.; DMOWSKA, K.; OSEK, J. Prevalence, characterization, and antimicrobial resistance of Listeria monocytogenes isolates from bovine hides and carcasses. Appl. Environ. Microbiol. 78, 2043-2045. 2012.

WIEDMANN, M. Molecular Subtyping Methods for Listeria monocytogenes. Journal of AOAC International, v. 85, n. 2, 2002. 